\title{
EDUCATIONAL WAGE PREMIA AND THE DISTRIBUTION OF EARNINGS: AN INTERNATIONAL PERSPECTIVE
}

\section{FRANCO PERACCHI}

Faculty of Economics, Tor Vergata University, via Columbia, 2, I-00133 Roma, Italy

e-mail: franco.peracchi@uniroma2.it

\section{Contents}

$\begin{array}{lr}\text { Abstract } & 190\end{array}$

$\begin{array}{ll}\text { Keywords } & 190\end{array}$

1. Introduction and summary 191

2. Measurement and statistical issues 192

2.1. Comparability of educational attainments 193

2.2. Aggregate data on schooling 195

2.3. Comparability of earnings data 197

$\begin{array}{ll}\text { 2.4. Statistical earnings functions } & 198\end{array}$

2.5. Measurement errors in micro-level data on schooling 201

3. Educational attainments 202

3.1. Educational composition of the population and the workforce 202

$\begin{array}{ll}\text { 3.2. A model of endogenous schooling } & 204\end{array}$

3.3. Life expectancy and schooling decisions 209

$\begin{array}{ll}\text { 3.4. Supply and demand } & 212\end{array}$

3.5. Expectations formations 216

4. Wage premia: Empirical evidence $\quad 217$

$\begin{array}{lr}\text { 4.1. Single-country studies } & 218 \\ & 218\end{array}$

$\begin{array}{ll}\text { Developed economies } & 218\end{array}$

$\begin{array}{ll}\text { Transition economies } & 219\end{array}$

Developing economies $\quad 223$

$\begin{array}{ll}\text { 4.2. Multi-country studies } & 224\end{array}$

4.3. Studies based on harmonized cross-national data 230

$\begin{array}{ll}\text { The LIS } & 231\end{array}$

The ISSP 233

The ECHP 233

5. Education and the distribution of personal earnings 235

$\begin{array}{ll}\text { 5.1. Methodological aspects } & 236\end{array}$

Handbook of the Economics of Education, Volume 1

Edited by Eric A. Hanushek and Finis Welch

(C) 2006 Elsevier B.V. All rights reserved

DOI: 10.1016/S1574-0692(06)01005-1 
Europe versus the USA $\quad 245$

\begin{abstract}
This chapter analyzes the international evidence on the relationship between educational wage premia and the distribution of personal labor earnings. The aim is to review what is known about the contribution of differences in relative wages across schooling levels to the degree of variability, between countries and over time, in the pecuniary returns to work. Definition and measurement problems are of paramount importance in analyses of this kind, and so a large part of the chapter is devoted to some of these issues.
\end{abstract}

\title{
Keywords
}

educational wage premia, earnings functions, educational attainments, distribution of labor earnings

JEL classification: $\mathrm{I} 20, \mathrm{~J} 24, \mathrm{~J} 31$ 


\section{Introduction and summary}

This chapter analyzes the international evidence on the relationship between educational wage premia and the distribution of personal labor earnings. The aim is to review what is known about the contribution of differences in relative wages across schooling levels to the degree of variability, between countries and over time, in the pecuniary returns to work. Definition and measurement issues are of paramount importance when trying to address the seemingly simple question of how much schooling pays off. Hence, a large part of the chapter is devoted to these issues.

Educational wage premia are typically defined as the percentage difference between the mean labor earnings of people with different schooling levels. For example, the college wage premium (or college premium for short) is defined as the percentage difference between the mean earnings of people with a college degree and the mean earnings of people with only secondary education completed. Often wage premia are approximated by logarithmic differences. To ensure robustness to outliers or censoring, mean earnings are sometimes replaced by median earnings.

The size of educational premia depends on how schooling levels are defined. It also depends, in a more subtle way, on the time reference for the earnings flow and the way in which the returns to work are defined. Earnings may be defined on an hourly, weekly, monthly or annual basis. If weekly, monthly or annual earnings are considered, educational premia may depend on differences across educational levels in the distribution of hours worked per unit of time. Educational premia are usually computed excluding non-wage benefits, such as employer provided health insurance and pension coverage. They also exclude the effects of education on productivity in self-employment and nonpecuniary returns such as better health status, efficiency in home production, child care, etc. We know little about how the inclusion of all these elements may change the structure of the private returns to schooling.

The distribution of labor earnings is not the same as the distribution of income, and changes in the distribution of labor earnings do not necessarily and immediately translate into equivalent changes in the distribution of income. Analyses of the income distribution typically focus on the distribution of total household income or equalized total household income (that is, total household income divided by some equivalence scale). These income concepts differ from personal earnings for two reasons. One is the role of income earned by other household members. The other is the role of unearned income. Unearned income is especially important at the bottom and the top of the income distribution. The sources of unearned income also differ in the two tails. At the bottom, where unemployment or nonemployment are prevalent, a crucial role is played by transfer income (unemployment benefits, pension income, etc.). At the top, a crucial role is instead played by property income (mainly income from past savings).

In this chapter I follow the approach of the theory of human capital developed by Schultz (1961), Becker (1964, 1967), Ben-Porath (1967) and Mincer (1974). This approach postulates that schooling increases wages by directly increasing a worker's productivity. I shall not consider the ability signaling approach introduced by Spence 
(1974), which postulates that education is associated with higher wages because by acquiring higher education a worker signals to firms that she has higher innate ability than a worker with lower education. ${ }^{1}$ A central difference between the two approaches is the fact that, in the human capital theory, the schooling choice causes at least part of the productivity differences among workers, whereas in signaling models, schooling is correlated with differences among workers that exist prior to the schooling choice [Weiss (1995)].

I also distinguish between educational wage premia and returns to schooling. The latter are a measure of the causal effect of an extra year of schooling on a worker's earnings. ${ }^{2}$ The former represent a convenient statistical summary of the observed differences in the distribution of earnings across schooling levels, but need not have a causal interpretation.

I shall focus on three sets of questions:

1. How are workers distributed by schooling level across countries? How did this distribution change over time?

2. How do educational premia look like across countries, possibly controlling for sex and age or labor market experience? How did they change over time?

3. What is the role of the differences in educational premia and in the population distribution by schooling level in explaining the observed differences in the distribution of personal earnings both across countries and over time?

The remainder of this chapter is organized as follow. Section 2 deals with the crucial issue of comparability of educational attainments and earnings data across countries and over time, and with the problem of how to specify and interpret the statistical relationship between earnings and schooling. Section 3 summarizes the available evidence on differences and trends across countries in the educational composition of the population and the workforce. To help interpret these results, and to guide the discussion of the available empirical evidence, it also presents a simple model of endogenous schooling choice that somewhat resembles the earlier models of Becker $(1964,1967)$ and Ben-Porath (1967). Section 4 looks instead at the evidence on movements in wage premia over the last 2-3 decades, focusing on differences in time trends across countries. Finally, Section 5 considers how the differences in the evolution of the educational composition of the workforce and the wage premia help explain the differences in the distribution of labor earnings across countries and over time.

\section{Measurement and statistical issues}

Before addressing the three questions raised in the Introduction, a number of measurement and statistical issues need to be discussed. Measurement issues arise from the fact

\footnotetext{
1 See Chapter 8 by Lange and Topel in this Handbook.

2 See Chapter 7 by Heckman, Lochner and Todd in this Handbook.
} 
that educational attainments and earnings need not be defined or measured in ways that are fully consistent across countries and over time, which complicates the task of drawing inferences from the available data. The main statistical issues have to do with the specification of the statistical model for the relationship between earnings and schooling, and the conditions under which this model may be taken to represent the causal effect of schooling on earnings.

\subsection{Comparability of educational attainments}

How are educational attainments measured? Can they be compared across countries and over time? These questions routinely arise when using micro-economic survey data, where one faces the problem of comparing educational attainments across countries, or over time for the same country. After the seminal paper of Benhabib and Spiegel (1994), they have also received considerable attention in the literature on macroeconomic growth, where a key empirical issue is whether the initial differences in the level of schooling help explain the cross-country differences in GDP growth.

Perhaps the simplest measure of educational attainments is the number of years of full-time schooling completed. This measure has been criticized on several grounds. First, by not counting years of part-time study, it underestimates educational attainments. Second, it ignores differences in the curricular content of schooling within a given country. Third, it takes no account of cross-country differences in educational systems. Thus, for example, Freeman and Schettkat (2000a) argue that "years of education do not provide a particularly good measure of differences in schooling. ... If one compares formal schooling, it is necessary to go beyond years of schooling and establish some form of equivalence between ... educational attainments".

Comparative work on educational attainments and educational wage premia is largely based on the International Standard Classification of Education (ISCED), which was designed by the UNESCO in the early 1970's to serve "as an instrument suitable for assembling, compiling and presenting statistics of education both within individual countries and internationally" [UNESCO (1997)].

The present version of the classification, known as ISCED 1997, was approved by the UNESCO in 1997. Educational programs are cross-classified along two dimensions: level and field of education. The concept of educational level is based on the assumption that educational programs can be grouped into an ordered set of categories, broadly corresponding to the degree of complexity of their content. ISCED 1997 classifies educational programs into the following seven levels:

- Level 0: Pre-primary education (initial stage of organized instruction). Not compulsory in most countries. It is "designed primarily to introduce very young children to a school-type environment".

- Level 1: Primary education or first stage of basic education. It is "designed to give students a sound basic education in reading, writing and mathematics, along with an elementary understanding of other subjects, such as history, geography, natural 
science, social science, art and music". It covers in principle 5 to 6 years of fulltime schooling, and the customary or legal age of entry is between 4 and 7 years.

- Level 2: Lower secondary or second stage of basic education. It is typically designed to complete the provision of basic education. The programs at this level are usually more subject-focused, and require more specialized teachers. The end of this level, after some 9 years from the beginning of primary education, often coincides with the end of full-time compulsory schooling.

- Level 3: Upper secondary education. Typically starts at 15 or 16 years of age, at the end of full-time compulsory education. Instruction is even more subject-oriented and often teachers need to be more qualified than at ISCED level 2. Education can be general or pre-cocational (two types of education often aggregated) or vocational. Many programs enable access to ISCED level 5.

- Level 4: Post-secondary non-tertiary education. It consists of programs that are at the boundary between upper-secondary and post-secondary (tertiary) education, but cannot be considered as tertiary programs because they are not significantly more advanced than ISCED level 3 programs. Examples include pre-degree foundation courses or short vocational programs.

- Level 5: First stage of tertiary education. It consists of programs that last at least two years, have a more advanced educational content than ISCED levels 3 and 4 , but do not lead directly to an advanced research qualification.

- Level 6: Second stage of tertiary education. It consists of programs that lead to the award of an advanced research qualification (Ph.D. or Doctorate). They are devoted to advanced study and original research (and not based on course-work only), and typically require the submission of a thesis or dissertation of publishable quality.

There is considerable variation, both across countries at a given point in time and over time for the same country, in the length, structure and objectives of each of these levels. Just as an example, Table 1 presents the theoretical starting ages at ISCED levels 3 and 5 in the school year 2000-01 for the 15 countries of the European Union (EU). The theoretical length of ISCED level 3 ranges between 2 years in Netherlands, Spain and the UK, and 5 years in Austria and Italy.

An additional difficulty is the fact that the same level of education (either years of schooling or schooling level) may reflect very different levels of literacy in different countries. This is indicated quite clearly by the results of reading and mathematical and scientific literacy tests, such as those carried out through the OECD Programme for International Student Assessment (PISA). ${ }^{3}$ These studies also indicate considerable differences in performance within each education system. Such differences are often related to differences in "school quality", a rather vague concept that is meant to capture differences in school and student backgrounds, the human and financial resources available to schools, curricular differences, selection policies and practices, or the way in which teaching is organized and delivered.

${ }^{3}$ See OECD (2002). 
Table 1

Theoretical starting age at ISCED levels 3 (level 3A) and 5 (level 5A/5B) in the school year 2000-01 for the countries of the European Union

\begin{tabular}{lll}
\hline Country & Level 3 & Level 5 \\
\hline Austria & 14 & $18-19$ \\
Belgium & 14 & 18 \\
Denmark & $16-17$ & $20-21$ \\
Finland & 16 & 19 \\
France & 15 & 18 \\
Germany & 16 & 19 \\
Greece & 15 & 18 \\
Ireland & 15 & 18 \\
Italy & 14 & 19 \\
Luxembourg & 15 & 18 \\
Netherlands & 16 & 18 \\
Portugal & 15 & 18 \\
Spain & 16 & 18 \\
Sweden & 16 & 19 \\
UK & 16 & 18 \\
\hline
\end{tabular}

Source: Dunne (2003).

The problem of differences in school quality may be particularly serious for developing countries. ${ }^{4}$ Typical proxies for school-quality include the pupil-teacher ratios, the spending per pupil as a fraction of per-capita GDP, the ratio of average salaries of teachers to per-capita GDP, the length of the school year, and the fraction of students that are repeaters and drop out in primary and secondary school. In fact, most of these indicators are simply crude measures of inputs into the schooling production function.

Barro and Lee $(1996,1997)$ show big differences in these indicators, both across countries and over time. However, without knowledge of the schooling production function, it is not clear how these differences translate into differences in school quality. Hanushek and Kimko (2000) try to circumvent the problem by constructing direct measures of school quality for 39 countries by combining the information on international mathematics and science tests available through 1991.

\subsection{Aggregate data on schooling}

The main direct sources of aggregate data on schooling are population censuses and educational and labor force surveys. Various international organizations (OECD, UN, UNESCO, etc.) collect and try to harmonize these data to ensure comparability across countries and over time.

4 See Chapter 16 by Glewwe and Kremer in Volume 2 of this Handbook. 
Data availability varies widely across countries. When direct census or survey information is unavailable, school enrollment rates (the ratio of the number of students enrolled in a given educational level to the size of the population in the relevant age group) are often used to construct measures of average educational attainments.

For example, Kyriacou (1991) provides estimates of the average years of schooling of the workforce for a sample of 111 countries at five-year intervals over the period 1965-1985. He first estimates a relationship linking average years of schooling to lagged enrollment rates for an initial cross-section of countries, and then uses this relationship to predict schooling attainments for other countries and years.

Barro and Lee $(1993,1996)$ compute instead average years of completed education of the population aged $15+$ and $25+$, broken down by gender, by combining direct survey and census information for some countries with indirect information for other countries obtained from school enrollment data through the perpetual inventory method. ${ }^{5}$

Nehru, Swanson and Dubey (1995) completely ignore census or survey information and use UNESCO school enrollment data to construct time series of educational attainments via the perpetual inventory method adjusted for mortality and, whenever possible, grade repetition and dropouts. Accounting for grade repetition is particularly important in developing countries where enrollment rates may otherwise be grossly overestimated. Unfortunately, their database contains some implausible results.

The practice of using enrollment flows has been criticized by many. For example, Krueger and Lindahl (2001) argue that "despite their aggregate nature, available data on average schooling levels across countries are poorly measured, in large part because they are often derived from enrollment flows".

De la Fuente and Doménech $(2000,2001)$ focus on 21 high-income OECD countries and produce estimates of the fraction of the population aged $25+$ that attended (but not necessarily completed) the various educational levels. They exploit a variety of direct sources of information on educational attainments and remove several anomalies that seem to reflect changes in classification criteria and other inconsistencies of the underlying primary statistics. They explicitly avoid the use of flow estimates based on enrollment data because "they seem to produce implausible time profiles". Compared to the alternative series, their data indicate a larger role for human capital variables in empirical growth equations. ${ }^{6}$

The data set produced by Cohen and Soto (2002) is currently the most complete and comes closest to the data presented in national censuses and OECD or UNESCO databases. It covers 95 countries at ten-year intervals from 1960 to 2010. The data for 2010 are based on the estimates of educational attainments for the year 2000 and the population projections by age taken from the US Census Bureau Web page. The main

\footnotetext{
5 The most recent version of their data [Barro and Lee (2000)] comprises at least one observation for 142 countries, of which 107 have complete observations at five-year intervals from 1960 to 2000.

6 Similar conclusions are obtained by Bassanini and Scarpetta (2002), who show that the long-run elasticity of output per working-age person to the average years of education (about $6 \%$ per an additional year of education) is in line with the microeconomic literature on private returns to schooling.
} 
differences with respect to de la Fuente and Domenech $(2000,2001)$ are due to differences in classification and the methods used to distinguish between primary education and the first stage of secondary education.

It is worth noticing that the importance of measurement errors not only varies significantly across data sets, but also depends on which data transformation is used. De la Fuente and Ciccone (2003) argue that "two of the data sets most widely used in crosscountry empirical work, those by Kyriacou (1991) and Barro and Lee (various years), perform relatively well when the data are used in levels, but contain very little signal when the data are differenced. Recent efforts to increase the signal to noise ratio by de la Fuente and Doménech (2001) and Cohen and Soto (2002) seem to have been at least partially successfull, but even in these cases the potential estimation bias remains large".

\subsection{Comparability of earnings data}

Comparability of earnings data is another important issue. Differences across countries and over time may arise from differences in the data sources, the time reference for the earnings flow, the comprehensiveness of the definition of earnings, their tax treatment, etc. They may also arise from differences in data quality.

Household surveys (either cross-sectional or longitudinal) are the main source of information on earnings. Sometimes, administrative data are used, such as income tax records and administrative data from social security. Firm-level data are less frequently used. Relative to survey data, administrative data have the advantage that the earnings information is in principle more accurate. This advantage is often offset by the fact that background information may be limited or of poor quality.

Typically, the self-employed are excluded or their earnings are imputed using the earnings model for the employees. The reason is the difficulty of separating selfemployment income from risk premia and the returns to physical capital and entrepreneurial ability.

The time reference for the earnings flows varies, as earnings may be computed on an hourly, daily, weekly, monthly or annual basis. If defined on a daily, weekly, monthly or annual basis, educational premia may depend on differences in the number of hours worked per unit of time by each educational level. On the other hand, the practice of obtaining hourly, daily, weekly or monthly earnings by dividing reported annual earnings by reported hours, days, weeks or months worked per year may add substantial noise to the data. This is especially true when, for example, annual hours of work are obtained as the product of the reported number of weeks worked times the reported usual number of weekly hours of work.

If one is interested in analyzing the allocative role of wages, then earnings should be measured after taxes and transfers, and should include the non-pecuniary advantages of jobs. This is not always done. Educational wage premia are often computed before taxes and transfers, and are typically computed excluding non-wage benefits, such as employer provided health insurance, pension coverage and nursery services. They also 
exclude the effects of education on productivity in self-employment and non-pecuniary returns such as better health status, efficiency in home production, child care, etc. To what extent the inclusion of these elements may change the structure of private returns to schooling remains an open research issue.

A variety of measurement error problems in earnings data may potentially affect estimates of educational premia and earnings inequality.

First, earnings may be top-coded. In surveys, this typically occurs for confidentiality reasons. Administrative data may also be topcoded because, for some programs, only earnings up to a threshold are relevant. Top-coding biases estimated means and variances downwards but does not necessarily affect estimated percentiles.

Second, reported earnings may be subject to recall and rounding errors. For some categories of workers and some countries, reported earnings may actually be systematically misreported.

Third, a small fraction of individuals reports earnings that appear implausibly low or implausibly high. The log transformation may exacerbate the problem for low earnings. To limit the influence of these cases, it is common practice to drop wage observations below a threshold, and sometimes also above. This practice does not have a formal justification and may actually introduce biases in the estimation of mean, variances and regression relationships.

Fourth, earnings data subject to nonresponse or other forms of missingness may be "completed" by some imputation procedure before being released. Imputation methods vary considerably, but they are almost invariably based on the "missing at random" assumption. Empirical work is divided between two alternative practices. One ignores the fact that a fraction of the data has been imputed and treats them as genuinely occurring values, the other drops observations with imputed values. In both cases, the fact that earnings may not be missing at random creates problems, although of a different nature.

Finally, cross-country comparisons are complicated by differential movements in price levels and exchange rates. Results may be sensitive to the choice of the price indices and the way in which national currencies are converted into a common scale (for example, through exchange rates or purchasing power parities).

\subsection{Statistical earnings functions}

In broad terms, a statistical earnings function is a specification of the conditional distribution of log earnings $Y$ given $S=s$ years of (full-time) schooling and $X=x$ years of potential work experience (years since leaving full-time study). ${ }^{7}$ Instead of considering the whole conditional distribution, one typically focuses on the conditional mean $\mu(s, x)=\mathrm{E}(Y \mid S=s, X=x)$ and the conditional variance $\sigma^{2}(s, x)=\operatorname{Var}(Y \mid S=s$, $X=x$ ) of log earnings, or on selected conditional percentiles, such as the median, the upper and lower quartiles, or the upper and lower deciles.

\footnotetext{
7 Potential work experience is often conventionally defined as age minus years of schooling minus 6 .
} 
Depending on the data and the model assumptions, a statistical earnings function may provide a cross-sectional or a longitudinal description. In the first case, the function $\mu(s, \cdot)$ describes the variability of average earnings, at a given point in time, across people with $s$ years of schooling but different experience levels. In the second case, $\mu(s, \cdot)$ describes the expected path of earnings across the working life of people with $s$ years of schooling.

A typical assumption on statistical earnings functions is additive separability in $s$ and $x$. For example, the specification

$$
\mu(s, x)=\alpha+f(s)+g(x),
$$

where $f$ and $g$ are smooth functions, implies that $\partial \mu / \partial s$ does not depend on $x$ and $\partial \mu / \partial x$ does not depend on $s$. When $f(s)$ is linear and $g(x)$ is quadratic, one obtains the earnings function popularized by Mincer (1974)

$$
\mu(s, x)=\mathrm{E}(Y \mid S=s, X=x)=\alpha+\beta s+\gamma_{1} x+\gamma_{2} x^{2} .
$$

I shall refer to (1) as the Mincer model or standard human capital earnings function. Because years of schooling enter (1) linearly, it follows that $\mathrm{E}(Y \mid S=s+1, X=x)-$ $\mathrm{E}(Y \mid S=s, X=x)=\beta$. I shall refer to the parameter $\beta$ as the (Mincerian) return to education because, under certain conditions, ${ }^{8}$ it may be interpreted as the internal rate of return from the investment on one additional year of (full-time) schooling.

Model (1) is easily generalized by replacing the linear term in schooling and the quadratic term in potential experience by more flexible parametric specifications. ${ }^{9}$ A semi-parametric alternative is the partially linear model

$$
\mu(s, x)=\alpha+\beta s+g(x),
$$

where the function $g$ is left unspecified.

A closely related family of models is obtained when additive separability is retained, but years of schooling are replaced by a set of indicators for educational attainments. One interpretation of this model is that the unknown function $f(s)$ is approximated by a piecewise constant function. For example, with three mutually exclusive and totally exhaustive schooling levels (say, "compulsory", "upper secondary" or "high school", and "tertiary" or "college"), a possible specification of the conditional mean of log earnings is

$$
\mu\left(d_{2}, d_{3}, x\right)=\mathrm{E}\left(Y \mid D_{2}=d_{2}, D_{3}=d_{3}, X=x\right)=\eta+\sum_{j=2}^{3} \delta_{j} d_{j}+g(x),
$$

where $D_{2}$ and $D_{3}$ are $0-1$ indicators for completed high school and college, $\eta+g(x)$ is the mean of log earnings for a worker with only compulsory education and $x$ years

8 See, for example, Willis (1986) and Polachek and Siebert (1993).

9 See, for example, Heckman and Polachek (1994) and Murphy and Welch (1990). 
of potential experience, and $\delta_{2}$ and $\delta_{3}$ are the educational premia ${ }^{10}$ for workers with exactly the same number of years of potential experience.

When schooling is discretized into categories, the Mincer model (1) implies

$$
\mu\left(d_{2}, d_{3}, x\right)=\eta+\sum_{j=2}^{3} \delta_{j} d_{j}+\gamma_{1} x+\gamma_{2} x^{2},
$$

where

$$
\eta=\alpha+\beta \bar{S}_{1}, \quad \delta_{2}=\beta\left(\bar{S}_{2}-\bar{S}_{1}\right), \quad \delta_{3}=\beta\left(\bar{S}_{3}-\bar{S}_{1}\right),
$$

and $\bar{S}_{j}$ is the mean number of years of schooling of workers with the $j$ th schooling level. Notice that the ratio $\delta_{3} / \delta_{2}$ of the coefficients on the schooling indicators is equal to the ratio $\left(\bar{S}_{3}-\bar{S}_{1}\right) /\left(\bar{S}_{2}-\bar{S}_{1}\right)$ of the mean number of years that each level requires beyond compulsory schooling.

Sometimes, potential experience is not available because only a coarse classification by educational level is available and the career starting date cannot easily be determined [see Light (1998)]. In these cases, versions of models (1) and (2) are often estimated with potential experience replaced by age. This practice usually ignores the implications of the two models for the conditional mean of log earnings given schooling and age. For example, if (1) holds and potential experience is defined as $X=$ age $-S-6$, then

$$
\mathrm{E}(Y \mid S=s, \text { age }=a)=\theta_{1}+\theta_{2} s+\theta_{3} s^{2}+\theta_{4} a+\theta_{5} a^{2}+\theta_{6} a s,
$$

where $\theta_{1}=\alpha-6 \gamma_{1}+36 \gamma_{2}, \theta_{2}=\beta-\gamma_{1}+12 \gamma_{2}, \theta_{3}=\theta_{5}=-\theta_{6} / 2=\gamma_{2}$, and $\theta_{4}=\gamma_{1}-12 \gamma_{2}$. Thus, the conditional mean of log earnings now depends on the level and the square of both schooling and age, and on their cross-product.

Because schooling and potential experience are usually recorded as integer valued, a statistical earnings function may in principle be estimated fully nonparametrically at all $(s, x)$ combinations for which the sample size is large enough. Depending on the model specification, estimation methods for additive models or partially linear models may also be considered. Most frequently, however, the parametric models (1) and (2) are estimated from cross-sectional data using ordinary least squares (OLS). Ease of estimation and increasing data availability have resulted in hundreds of estimates of Mincerian returns to schooling from model (1) or educational premia from model (2) for a large number of countries and different periods.

The econometric problems arising when OLS are used to uncover the returns to schooling, that is, the causal effect of one additional year of schooling on the distribution of earnings, have been discussed at length in the literature. ${ }^{11}$ These problems include endogeneity of schooling, measurement errors in schooling and potential experience, omitted unobserved individual effects ("ability"), heterogeneity of returns, and

\footnotetext{
10 The difference in the mean of log earnings relative to compulsory education.

11 See, for example, the classical paper of Griliches (1977) and the more recent papers by Card (2001) and Harmon, Oosterbeek and Walker (2003).
} 
sample selection due to either self-selection or the sample inclusion criteria adopted by the analyst. ${ }^{12}$

To tackle the resulting biases, various estimation methods have been proposed. In recent years, two approaches have received considerable attention. The first exploits the differences between siblings or twins in the levels of schooling and earnings. The second employs instrumental variables (IV) techniques using a wide range of instruments typically provided by "natural experiments". The estimates of returns to education obtained from these approaches usually exceed OLS estimates, although this is not true in general. ${ }^{13}$ They also tend to be less precise than OLS, possibly because of a weak instrument problem. ${ }^{14}$

Ashenfelter, Harmon and Oosterbeek (1999) argue that, in fact, differences due to the estimation method are much smaller than is sometimes reported. The reason is that estimated returns that are significantly different from zero are more likely to be published and, since the twin studies and IV studies tend to have larger sampling errors in general, a less representative sample of these studies is typically reported.

Recently, the specifications (1) and (2) (and their generalizations) have also been used to model the behavior of the quantiles of the conditional distribution of log earnings given schooling and labor market experience (or age). If $\xi_{u}(s, x)$ denotes the $u$ th conditional quantile of log earnings $(0<u<1),{ }^{15}$ then the counterpart of model (1) is the linear quantile regression model

$$
\xi_{u}(s, x)=\alpha+\beta s+\gamma_{1} x+\gamma_{2} x^{2},
$$

where now the parameters $\alpha, \beta, \gamma_{1}$ and $\gamma_{2}$ all vary with $u$, unless the conditional distribution of log earnings is homoskedastic, in which case only the intercept $\alpha$ varies with $u$. The linear quantile regression model is typically estimated by minimizing an asymmetric least absolute deviations criterion using some version of the simplex method.

\subsection{Measurement errors in micro-level data on schooling}

When individual's education appears as a regressor in a model for some labor market outcome, the validity of inference depends crucially on how accurately educational attainments are measured. The presence of measurement errors in micro-level data on schooling has been recognized for long time. ${ }^{16}$ Assessments of their effects on inference about population earnings functions and attempts to correct for their presence typically

\footnotetext{
12 For example, focusing only on full-time full-year workers or private-sector non-agricultural employees.

13 See, for example, the results of Vieira (1999) for Portugal.

14 See, for example, Bound, Jaeger and Baker (1995).

15 By definition, $\xi_{u}(s, x)=\inf \{y: F(y \mid s, x) \leqslant u\}$, where $F(\cdot \mid s, x)$ is the conditional distribution function of log earnings given schooling and labor market experience. If $u=.5$, then $\xi_{u}(s, x)$ is simply the conditional median of log earnings. By the properties of quantiles, $\exp \xi_{u}(s, x)$ is the conditional quantile of earnings.

16 See, for example, Griliches (1977).
} 
rest on the assumption that they obey the classical measurement errors model, which essentially treats them as random. How good is this model?

Black, Sanders and Taylor (2003) document the nature of measurement errors in the reporting of higher education in the US Census and Current Population Survey (CPS) data. They find that these errors violate models of classical measurement error in three important ways. First, the level of education is consistently reported as higher than it is. Second, errors in the reporting of education are correlated with covariates that enter the earnings regressions. Third, errors in the reporting of education appear to be correlated with the error term in a model of earnings determination. These findings are unlikely to be unique to the USA.

They conclude that "because measurement error in education is systematically related to both observed earnings-related characteristics and the error term in earnings regressions, it is likely that measurement error is positively correlated across multiple reports on education. If so, instrumental variable (IV) estimates, that rely on multiple reports of education are inconsistent, as are other recently proposed estimators designed to deal with these biases".

\section{Educational attainments}

Section 3.1 presents international evidence on educational attainments of the population and the workforce over the last 40 years. Although the available data can only provide a broad-brush picture of the differences and trends across countries, they show clear evidence of substantial increases of educational attainments in both developing and developed countries. To help interpret these results, and to guide the discussion of the empirical evidence on educational wage premia, Section 3.2 presents a simple model of endogenous schooling choice that resembles the earlier models of Becker $(1964,1967)$ and Ben-Porath (1967). The model suggests an important link between schooling attainments and life expectancy, on which Section 3.3 provides some empirical evidence. Finally, Sections 3.4 and 3.5 discuss two crucial aspects which are neglected by the basic model, namely the interaction between supply and demand and the role of expectations about future wage premia.

\subsection{Educational composition of the population and the workforce}

How is the population distributed by educational level across countries? How is the workforce distributed by educational level across countries? How did these distributions change over time?

Figure 1 plots changes in the educational attainments of the adult population (aged 25+) between 1960 and 2000 against their initial level in 1960. The data are from Cohen and Soto (2002), and cover 95 countries. I present four indicators: the percentage of the adult population with primary, secondary and higher education, and the average number of years of schooling. 


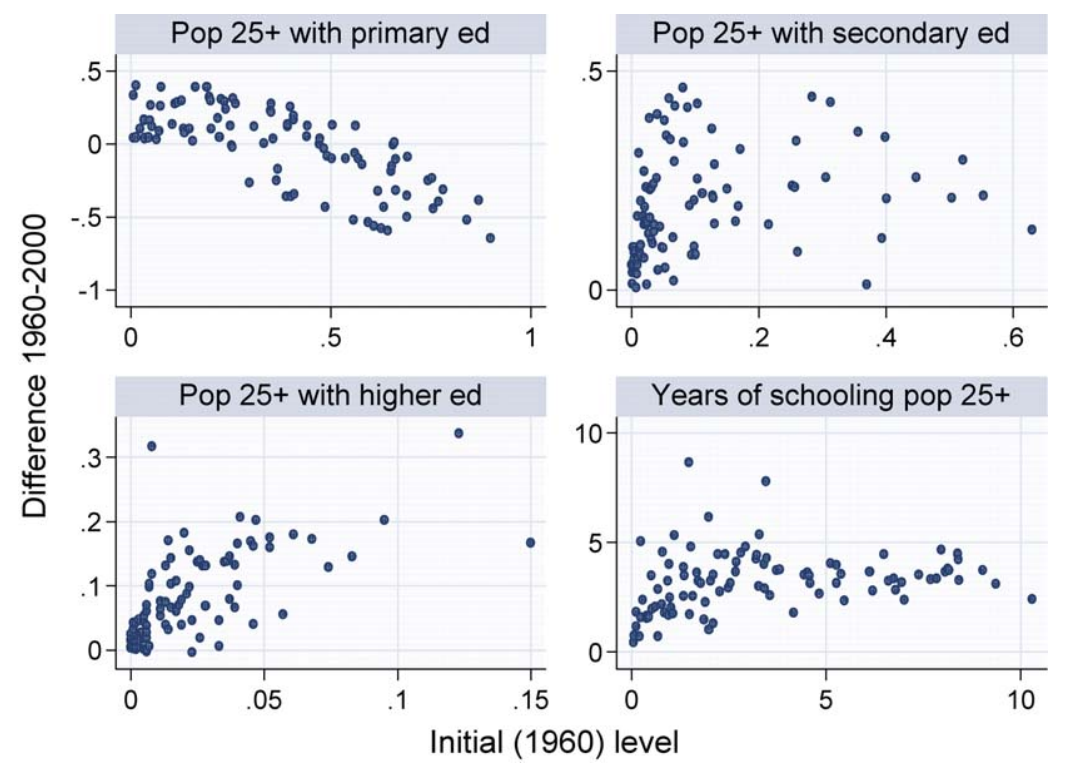

Figure 1. Educational attainments of the population aged 25+ in 1960 and differences between 1960 and 2000 .

Between 1960 and 2000, educational attainments increased in both developing and developed countries. On average across countries, the percentage of the adult population with only primary education hardly changed as a result of an increase in developing countries $^{17}$ and a decline in developed countries. On the other hand, the percentage of the adult population with secondary education increased by 19 percentage points, the percentage of the adult population with tertiary education increased by about 8 percentage points, whereas the mean number of years of schooling increased by 3.2 years.

The available data show clear evidence of convergence in the percentage of the adult population with only primary education (Figure 1). In fact, the relationship between initial levels and subsequent variation has a negative slope, and one may also observe a decline in the cross-country variation of this indicator. On the other hand, the data show no evidence of convergence for the percentage of the adult population with secondary or higher education, and for the mean number of years of schooling. For these indicators, the available evidence actually shows a substantial increase in cross-country variation.

Much less is known about the educational composition and the educational attainments of the workforce, and their changes over time. Because better educated people tend to have higher labor force participation, the worksforce tends to exhibit higher

17 An important, but largely unresolved issue, is the role played by prohibition on child labor, increases in mandatory schooling, and various education policies (literacy campaigns, educational radio, etc.) in raising educational attainments in developing countries [see, for example, Glewwe (2002)]. 
educational attainments than the population as a whole. Thus, the educational attainments of the population provide a lower bound on the educational attainments of the workforce. In general, increases in the educational attainments of the population and the workforce are highly correlated. The precise effect, however, depends on the labor force participation rate of each educational group relative to the aggregate.

\subsection{A model of endogenous schooling}

To understand the forces behind the massive increase of educational attainments documented in Section 3.1, I now present a partial equilibrium model of schooling choice that may be viewed as the finite-horizon, discrete-time counterpart of the infinite-horizon, continuous-time model used by Card and Lemieux (2000) and Card (2001). It may also be viewed as a simplified version of the microeconomic choice model of Heckman, Lochner and Taber (1998), as I do not consider the equilibrium effects of human capital accumulation decisions and treat earnings by schooling level as exogenous.

At the minimum school-leaving age $(t=0)$, a person with a planning horizon of $M$ years (her known residual life length) decides a consumption path $\left\{c_{t}\right\}=$ $\left(c_{0}, c_{1}, \ldots, c_{M}\right)$ and a level $S$ of post-compulsory schooling in order to maximize her lifetime utility. I assume that there are $J+1$ schooling levels, indexed by the number of extra years $0=S_{0}<S_{1}<\cdots<S_{J}$ that they require, $S_{0}$ being the level associated with compulsory schooling. Leaving school is an irreversible decision.

Under these assumptions, lifetime utility may be written

$$
V\left(S,\left\{c_{t}\right\}\right)=\sum_{t=0}^{S} \beta^{t} u\left(c_{t}-\phi_{t}\right)+\sum_{t=S+1}^{M} \beta^{t} u\left(c_{t}\right),
$$

where $\beta$ is the rate of time preference, $u(\cdot)$ is a smooth function, and $\phi_{t}$ is the relative disutility of school versus work for the $t$ th year of extra schooling. It is useful to write (3) more compactly as

$$
V\left(S,\left\{c_{t}\right\}\right)=\sum_{t=0}^{M} \beta^{t} u\left(c_{t}-\phi_{S, t}\right),
$$

where $\phi_{S, t}$ is equal to $\phi_{t}$ if $t \leqslant S$ and is equal to zero otherwise. The lifetime budget constraint is

$$
\sum_{t=0}^{M} \gamma^{t} c_{t}=\sum_{t=0}^{S} \gamma^{t}\left(p_{t}-T_{t}\right)+\sum_{t=S+1}^{M} \gamma^{t} y_{S, t},
$$

where $\gamma=1 /(1+R), R$ is the real interest rate (assumed fixed), $p_{t}$ are part-time earnings while at school, $T_{t}$ are tuition costs, and $y_{S, t}$ are post-schooling earnings of a person with schooling level $S$. Notice that earnings are defined in broad terms and include unemployment benefits and work-related pensions received after retirement. 
This simple model suggests that differences in educational attainments across countries and over time may arise because of differences in the rate of time preference $(\beta)$, the length of a person's planning horizon $(M)$, the taste for school versus work $\left(\phi_{t}\right)$, the real interest rate $(R)$, the expected age profile of earnings by schooling level $\left(\left\{y_{S, t}\right\}\right)$, part-time earnings while at school $\left(p_{t}\right)$, and tuition costs $\left(T_{t}\right)$. For simplicity, $M, \phi_{t}, p_{t}$ and $T_{t}$ are all assumed not to depend on the level of schooling.

The choice problem may be solved in two stages. First, an optimal lifetime consumption path is chosen for each schooling level, resulting in a specific value of lifetime utility. Then the person selects the schooling level that gives the highest value of lifetime utility.

For a given schooling level $S$, a consumption path $\left\{c_{t}\right\}$ is optimal if it satisfies

$$
\beta \frac{u^{\prime}\left(c_{t}-\phi_{S, t}\right)}{u^{\prime}\left(c_{t-1}-\phi_{S, t-1}\right)}=\gamma \text {. }
$$

Given a consumption path $\left\{c_{t}\right\}$ which is optimal for $S$, the lifetime utility associated with schooling level $S$ is simply $V_{S}=V\left(S,\left\{c_{t}\right\}\right)$. An optimal schooling level $S^{*}$ is one for which the associated lifetime utility is highest. Letting $V^{*}=V_{S^{*}}$ and $V_{j}=V_{S_{j}}$, the optimal schooling level $S^{*}$ is characterized by the set of $J+1$ inequalities $V^{*} \geqslant V_{j}$ for all $j=0,1, \ldots, J$. Equivalently, letting $\Delta V^{*}=V^{*}-V_{0}$ and $\Delta V_{j}=V_{j}-V_{0}, S^{*}$ is characterized by the set of $J$ inequalities $\Delta V^{*} \geqslant \Delta V_{j}$ for all $j=1, \ldots, J$. If the $\Delta V_{j}$ are all negative, then the optimal choice is to take only compulsory schooling.

In order to obtain analytical results, I follow the common practice of assuming $u(c)=$ $\ln c$. Condition (5) then becomes

$$
c_{t}-\phi_{S, t}=\alpha\left(c_{t-1}-\phi_{S, t-1}\right),
$$

where $\alpha=\beta / \gamma$. Thus

$$
c_{t}-\phi_{S, t}=\alpha^{t}\left(c_{0}-\phi_{0}\right),
$$

and therefore

$$
\sum_{t=0}^{M} \gamma^{t} c_{t}=\sum_{t=0}^{M} \gamma^{t}\left(c_{t}-\phi_{S, t}\right)+\sum_{t=0}^{M} \gamma^{t} \phi_{S, t}=\left(c_{0}-\phi_{0}\right) G+\sum_{t=0}^{S} \gamma^{t} \phi_{t},
$$

where $G=\sum_{t=0}^{M} \beta^{t}>0$. Hence, from the budget constraint (4),

$$
\left(c_{0}-\phi_{0}\right) G=\sum_{t=0}^{S} \gamma^{t}\left(p_{t}-T_{t}-\phi_{t}\right)+\sum_{t=S+1}^{M} \gamma^{t} y_{S, t},
$$

so $c_{0}-\phi_{0}=Y_{S} / G$, where

$$
Y_{S}=\sum_{t=0}^{S} \gamma^{t}\left(p_{t}-T_{t}-\phi_{t}\right)+\sum_{t=S+1}^{M} \gamma^{t} y_{S, t} .
$$


If $\phi_{t}=0$ for all $t$, then $Y_{S}$ is just the person's net wealth. Under logarithmic utility, the lifetime utility function (3) is therefore

$$
V\left(S,\left\{c_{t}\right\}\right)=\sum_{t=0}^{M} \beta^{t} \ln \left(c_{t}-\phi_{S, t}\right)
$$

where $c_{t}-\phi_{S, t}=\alpha^{t} Y_{S} / G$. Hence, the lifetime utility associated with schooling level $S$ is

$$
V_{S}=\sum_{t=0}^{M} \beta^{t}\left(t \ln \alpha+\ln Y_{S}-\ln G\right),
$$

and the difference in lifetime utility relative to the case of only compulsory schooling is

$$
V_{S}-V_{0}=\left(\ln Y_{S}-\ln Y_{0}\right) \sum_{t=0}^{M} \beta^{t}=G \ln \frac{Y_{S}}{Y_{0}},
$$

where $Y_{0}=p_{0}-T_{0}-\phi_{0}+\sum_{t=1}^{M} \gamma^{t} y_{S_{0}, t}$.

Given any two schooling levels $S_{1}<S_{2}$, level $S_{2}$ is preferred to $S_{1}$ whenever $V_{2}-V_{1}=G \ln \left(Y_{2} / Y_{1}\right)>0$, with $Y_{j}=Y_{S_{j}}, j=1,2$. Since $G>0, S_{2}$ is preferred to $S_{1}$ whenever $Y_{2}>Y_{1}$, that is, whenever

$$
\sum_{t=0}^{S_{2}} \gamma^{t}\left(p_{t}-T_{t}-\phi_{t}\right)+\sum_{t=S_{2}+1}^{M} \gamma^{t} y_{2, t}>\sum_{t=0}^{S_{1}} \gamma^{t}\left(p_{t}-T_{t}-\phi_{t}\right)+\sum_{t=S_{1}+1}^{M} \gamma^{t} y_{1, t},
$$

where $y_{j, t}=y_{S_{j}, t}$. Because $p_{t}, T_{t}$ and $\phi_{t}$ are assumed not to depend on the level of schooling, it follows that $S_{2}$ is preferred to $S_{1}$ whenever

$$
\sum_{t=S_{2}+1}^{M} \gamma^{t}\left(y_{2, t}-y_{1, t}\right)>\sum_{t=S_{1}+1}^{S_{2}} \gamma^{t} y_{1, t}+\sum_{t=S_{1}+1}^{S_{2}} \gamma^{t}\left(T_{t}-p_{t}+\phi_{t}\right)
$$

that is, the present value of the earnings differential associated with the higher level of schooling is greater than the sum of two components: the present value of forgone earnings and the present value of the net costs (monetary costs plus relative disutility) of extra schooling. An interesting feature of this result is that the choice between $S_{1}$ and $S_{2}$ depends on the real interest rate $R$ and the length $M$ of the planning horizon, but not on the rate of time preference $\beta$.

Now assume that the earnings function is of the form

$$
y_{S, t}=f_{S} h(t-S), \quad t>S,
$$

that is, log earnings are additively separable in schooling and potential work experience $t-S$. Then

$$
\sum_{t=S_{1}+1}^{S_{2}} \gamma^{t} y_{1, t}=f_{1} \sum_{t=S_{1}+1}^{S_{2}} \gamma^{t} h\left(t-S_{1}\right)
$$


and

$$
\sum_{t=S_{2}+1}^{M} \gamma^{t}\left(y_{1, t}-y_{2, t}\right)=\sum_{t=S_{2}+1}^{M} \gamma^{t}\left[f_{2} h\left(t-S_{2}\right)-f_{1} h\left(t-S_{1}\right)\right],
$$

where $f_{j}=f_{S_{j}}, j=1,2$. In the special case when earnings do not depend on potential work experience, that is, $h(t)=1$ for all $t>S$, one has

$$
\sum_{t=S_{1}+1}^{S_{2}} \gamma^{t} y_{1, t}=f_{1} \sum_{t=S_{1}+1}^{S_{2}} \gamma^{t}
$$

and

$$
\sum_{t=S_{2}+1}^{M} \gamma^{t}\left(y_{1, t}-y_{2, t}\right)=\left(f_{2}-f_{1}\right) \sum_{t=S_{2}+1}^{M} \gamma^{t} .
$$

Under the further assumption that $p_{t}=T_{t}$ and $\phi_{t}=0$ for all $t, S_{2}$ is preferred to $S_{1}$ whenever

$$
\left(f_{2}-f_{1}\right) \sum_{t=S_{2}+1}^{M} \gamma^{t}>f_{1} \sum_{t=S_{1}+1}^{S_{2}} \gamma^{t}
$$

that is, whenever

$$
\frac{f_{2}-f_{1}}{f_{1}}>\frac{\sum_{t=S_{1}+1}^{S_{2}} \gamma^{t}}{\sum_{t=S_{2}+1}^{M} \gamma^{t}},
$$

where $\left(f_{2}-f_{1}\right) / f_{1}$ is the educational wage premium. Because

$$
\sum_{t=a+1}^{b} \gamma^{t}=\gamma^{a+1}\left(\frac{1-\gamma^{b-a}}{1-\gamma}\right)
$$

it follows that $S_{2}$ is preferred to $S_{1}$ whenever $\left(f_{2}-f_{1}\right) / f_{1}>\kappa$, where

$$
\kappa=\frac{\sum_{t=S_{1}+1}^{S_{2}} \gamma^{t}}{\sum_{t=S_{2}+1}^{M} \gamma^{t}}=\frac{\gamma^{S_{1}}}{\gamma^{S_{2}}}\left(\frac{1-\gamma^{S_{2}-S_{1}}}{1-\gamma^{M-S_{2}}}\right)=\frac{\gamma^{S_{1}-S_{2}}-1}{1-\gamma^{M-S_{2}}} .
$$

Notice that the threshold value $\kappa$ of the educational wage premium depends negatively on the length $M$ of the planning horizon (residual life expectancy), and positively on the real interest rate $R$ and the difference $S_{2}-S_{1}$ in the years of schooling required to reach the higher level. When $M$ is short, a large educational premium is needed to induce a person to acquire more schooling. On the other hand, when $M$ gets longer, smaller educational premia are required. Because expected life length and level of economic 
development are strongly positively correlated, this prediction of the model is consistent with the observed evidence of falling returns to education by level of economic development. ${ }^{18}$

In the special case when $S_{2}=S_{1}+1$, the condition for choosing $S_{2}$ over $S_{1}$ becomes

$$
\frac{f_{2}-f_{1}}{f_{1}}>\frac{\gamma^{-1}-1}{1-\gamma^{M-S_{2}}}=\frac{R}{1-\gamma^{M-S_{2}}} .
$$

If $M \rightarrow \infty$, that is, the person has an infinite planning horizon, then $\left(f_{2}-f_{1}\right) / f_{1}>R$, which is the discrete-time analog of the classical condition that equates the marginal return on an extra unit of schooling to the instantaneous real interest rate. ${ }^{19}$

Suppose that $S_{1}$ and $S_{2}$ are the only possible educational levels. If the educational premium $\left(f_{2}-f_{1}\right) / f_{1}$ varies across individuals and its variability is well described by some distribution function $G$, then the fraction of the population taking the higher educational level is equal to

$$
\pi=\operatorname{Pr}\left\{\frac{f_{2}-f_{1}}{f_{1}}>\kappa\right\}=1-G(\kappa) .
$$

In particular, if $G$ is the Gaussian distribution function with mean $\mu$ and variance $\sigma^{2}$, then

$$
\pi=1-\Phi\left(\frac{\kappa-\mu}{\sigma}\right)=\Phi\left(\frac{\mu-\kappa}{\sigma}\right),
$$

where $\Phi(\cdot)$ denotes the distribution function of the standardized Gaussian distribution.

The model just described has several implications for the behavior of $\pi$. First, other things being equal, a shift to the right of the distribution of educational premia (for example, an increase in its mean leaving its shape unchanged) increases $\pi$. On the other hand, a mean preserving spread increases $\pi$ if $\pi<1 / 2$ and lowers $\pi$ if $\pi>1 / 2$.

Second, if the planning horizon $M$ increases, then the threshold value $\kappa$ of the educational premium decreases and $\pi$ increases. Notice that $M$ changes with life expectancy and the number of years of compulsory schooling. Other things being equal, if life expectancy increases then $\pi$ increases. On the other hand, if the number of years of compulsory education increases, then $M$ decreases and so $\pi$ decreases. Nothing instead happens if the number of years of compulsory education and life expectancy increase by the same amount.

Third, other things being equal, a decline of the real interest rate $R$, due to either improvements in the credit markets or to reduced risk, lowers the threshold value $\kappa$ and therefore increases $\pi$. If $R$ is re-interpreted as the difference between the real interest rate and the macroeconomic growth rate of wages [as in Bils and Klenow (2000)], then higher macroeconomic growth also induces more schooling.

18 See Psacharopoulos (1994) and Psacharopoulos and Patrinos (2002).

19 See, for example, Willis (1986). 
All three forces may have contributed to the worldwide increase of college education after the Second World War and other historical episodes, such as the great expansion of secondary education in the USA from 1910 to 1940, documented by Goldin (1999), and the sharp increase of household investment in schooling in rural India after the green revolution, documented by Foster and Rosenzweig (1996).

Goldin (1999) explains the "secondary school movement" in the USA as the result of an income effect and changes in labor demand driven by both the technological revolution in the industrial sector and shifts towards the services. These two explanations are not entirely convincing. If it was changes in labor demand, why did the "secondary school movement" start and develop in rural America? If education is mainly an investment, why should changes in income matter so much? Of course, several explanations are possible for a positive income effect on the demand for schooling. For example, Schultz (1963) argues that attending classes may be less onerous than working, especially in developing countries, and that higher education may increase one's ability to enjoy consumption throughout life. Other explanations are that higher income may reduce the importance of borrowing constraints, and that increases in average income may lead to the availability of more schools and therefore to more schooling.

My finite-horizon model suggests a different explanation that requires neither a shift in labor demand nor a positive income effect on the demand for schooling. More simply, increases in productivity and income in rural areas lead to more favorable survival prospects. Assuming that credit markets are not dramatically imperfect, and barring general equilibrium effects, this makes schooling investments more profitable and lead people to acquire more education. These effects are clearly reinforced if more schooling implies better health, and therefore higher survival probabilities and longer life expectancy [see, e.g., Lleras-Muney (2002)].

\subsection{Life expectancy and schooling decisions}

I now present some empirical evidence on the relationship between schooling attainments and life expectancy. Somewhat surprisingly, this relationship has received little attention in the literature, maybe because of data limitations. Ideally, one would need information on residual life expectancy at the age when compulsory education ends. This age varies considerably across countries, ranging between 9 and 18 years. Further, data on residual life expectancy at various ages for a sufficiently large number of countries can only be found for recent years.

Figure 2 shows the relationship between life expectancy at birth and residual life expectancy at age 10 in year $2000 .{ }^{20}$ In countries where life expectancy at birth is high, residual life expectancy at age 10 is about 10 years shorter than at birth. In countries where life expectancy at birth is low, however, residual life expectancy at age 10 is often higher than at birth (Figure 3). As a result, cross-country variability in residual

20 The data are from the database maintained by the World Health Organization. 


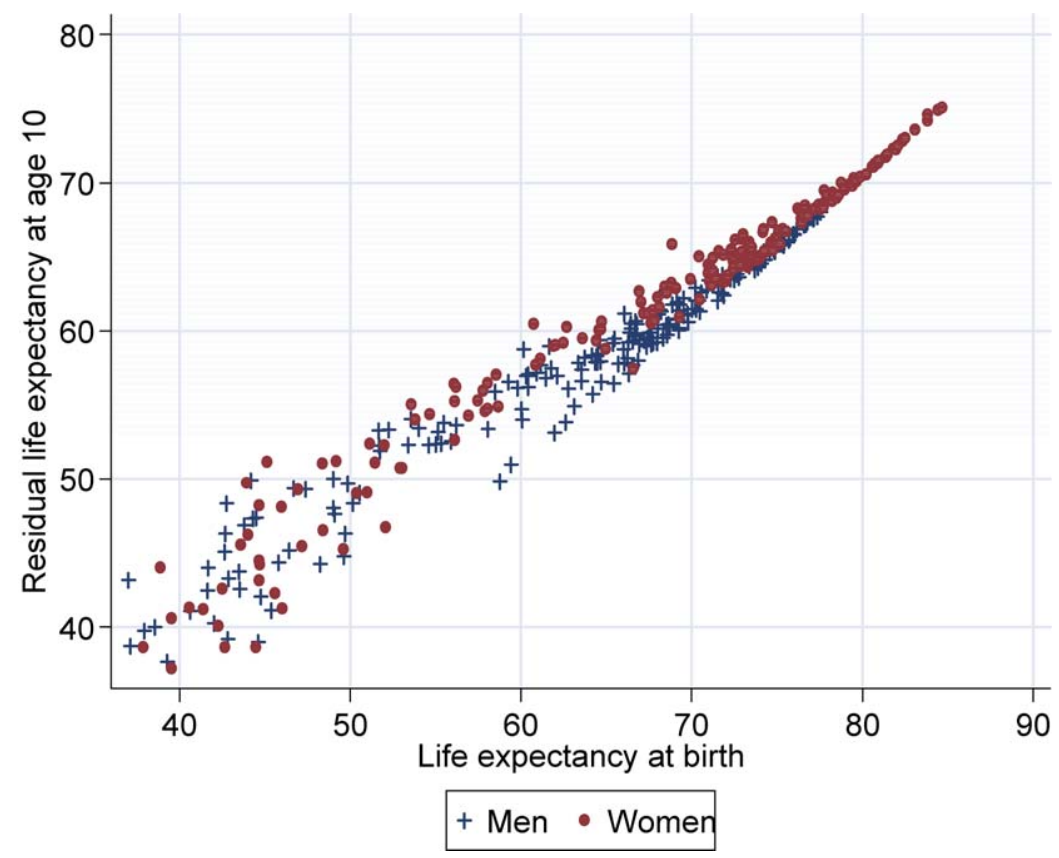

Figure 2. Life expectancy at birth and residual life expectancy at 10 years of age. Year 2000.

life expectancy declines with age, and is much higher at birth than at later ages. Despite this "convergence" process, the ranking of countries in terms of residual life expctancy does not change much with age. Table 2 shows the Spearman rank correlation coefficient between life expectancy at birth and life expectancy at various ages, separately for men and women. The correlation between the various measures is remarkably high up to age 60, which justifies focusing on the relationship between life expectancy at birth and schooling attainments.

Figure 4 plots the increase in life expectancy at birth between 1960 and 2000 against its initial level in $1960 .^{21}$ The figure shows an increase in life expectancy for most countries considered and a remarkable reduction of the differences across countries. As pointed out by Bourguignon and Morrisson (2002), this convergence in life expectancy contrasts sharply with the pattern of divergence in per-capita GDP. The convergence process has two notable features, however. First, life-expectancy actually fell in some countries of the former Soviet Union (Belarus, Russia and Ukraine) and in many subSaharan countries. Second, the pattern of convergence for the sub-Saharan countries is

21 The data are from the Population Division of the Department of Economic and Social Affairs of the UN Secretariat. 


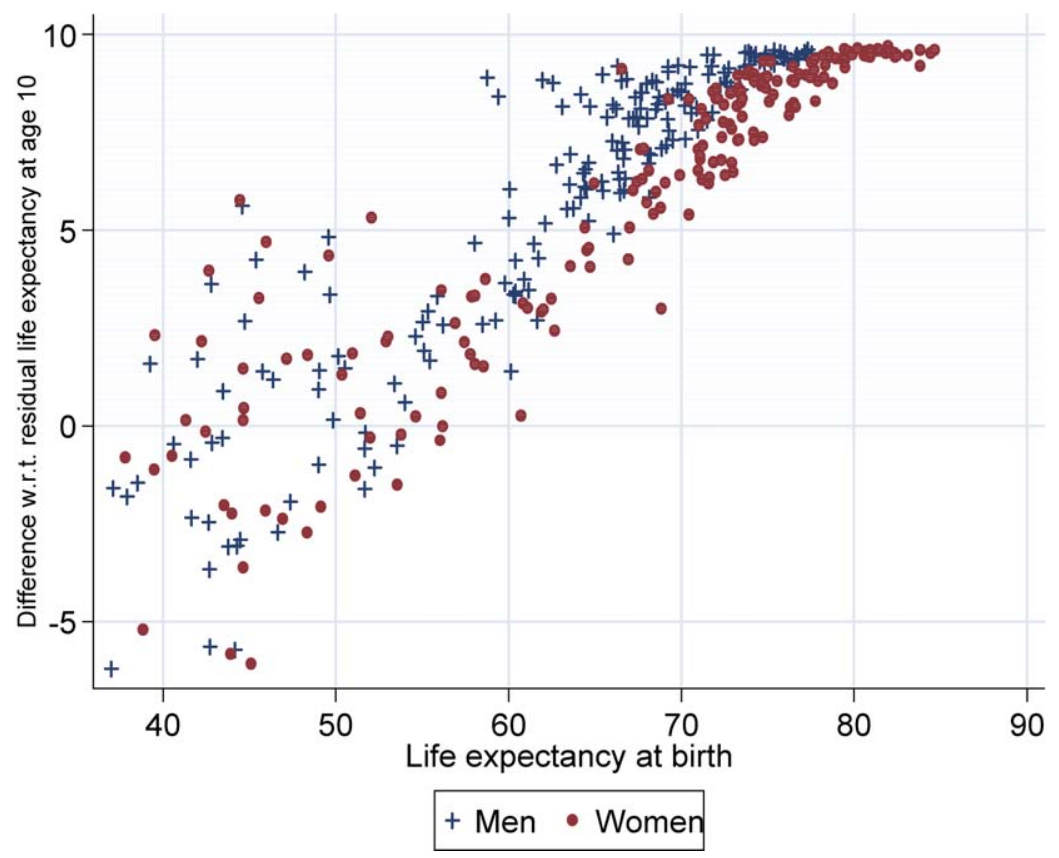

Figure 3. Life expectancy at birth and difference with respect to residual life expectancy at 10 years of ag. Year 2000.

quite different from the other countries considered, as increases in life expectancy are much lower for each initial level.

Figures 5-7 show the relationship between changes in life expectancy and changes in various measures of schooling attainments over the period 1960-2000 for the 95 countries in the Cohen and Soto (2002) data set. The relationship is positive but not particularly strong. In fact, Cohen and Soto (2002) observe that "the reduction of worldwide inequalities regarding life expectancy has not been channeled into a convergence of education patterns across the world". They argue that, over the past 30 years, nearly half of the increase of life expectancy in rich countries has been translated into higher education, but only one fourth in poor countries.

As an answer to this puzzle, ${ }^{22}$ Cohen and Soto (2002) produce a model that exhibits a nonlinear relationship between education and life expectancy. Below a critical value $T^{*}$ of life expectancy, increases in life expectancy are entirely channeled into worklife. Above $T^{*}$, the level of education rises with life expectancy and, for large values of life expectancy, the lengthening of life is entirely channeled into education. They also estimate a simple nonlinear cross-sectional relationship between average years of schooling 
Table 2

Spearman rank correlation coefficient between life expectancy at birth and life expectancy at various ages. Year 2000

\begin{tabular}{rll}
\hline Age & Men & Women \\
\hline 1 & .992 & .995 \\
5 & .985 & .989 \\
10 & .983 & .988 \\
15 & .981 & .987 \\
20 & .978 & .985 \\
25 & .975 & .983 \\
30 & .967 & .981 \\
35 & .962 & .979 \\
40 & .955 & .976 \\
45 & .947 & .972 \\
50 & .937 & .965 \\
55 & .922 & .954 \\
60 & .909 & .944 \\
65 & .890 & .930 \\
70 & .867 & .911 \\
75 & .825 & .877 \\
80 & .751 & .832 \\
85 & .670 & .772 \\
90 & .610 & .720 \\
95 & .586 & .675 \\
100 & .553 & .652 \\
\hline
\end{tabular}

in the population aged 25-29 and life expectancy at age 5, and show that education starts rising significantly only when life expectancy at 5 is above 55 . Their estimates imply that the poorest countries are only in the early stage of their education pattern.

\subsection{Supply and demand}

The model in Section 3.2 is a partial equilibrium model where individuals make their educational choices taking educational premia and institutional settings as given. In fact, as documented in Section 4 below, educational premia show remarkable variation both over time and across countries. Understanding the sources of this variation requires moving to a more general model where wage premia are determined by the interaction of market forces, namely supply and demand of the various kinds of labor, and labor market institutions (wage setting norms, unionization, minimum wages, unemployment benefits and income maintenance programs) that may ease or limit the operation of market forces.

Welch (1970) was among the first to ask the question of what explains the relative stability of educational premia during historical episodes characterized by a sustained 


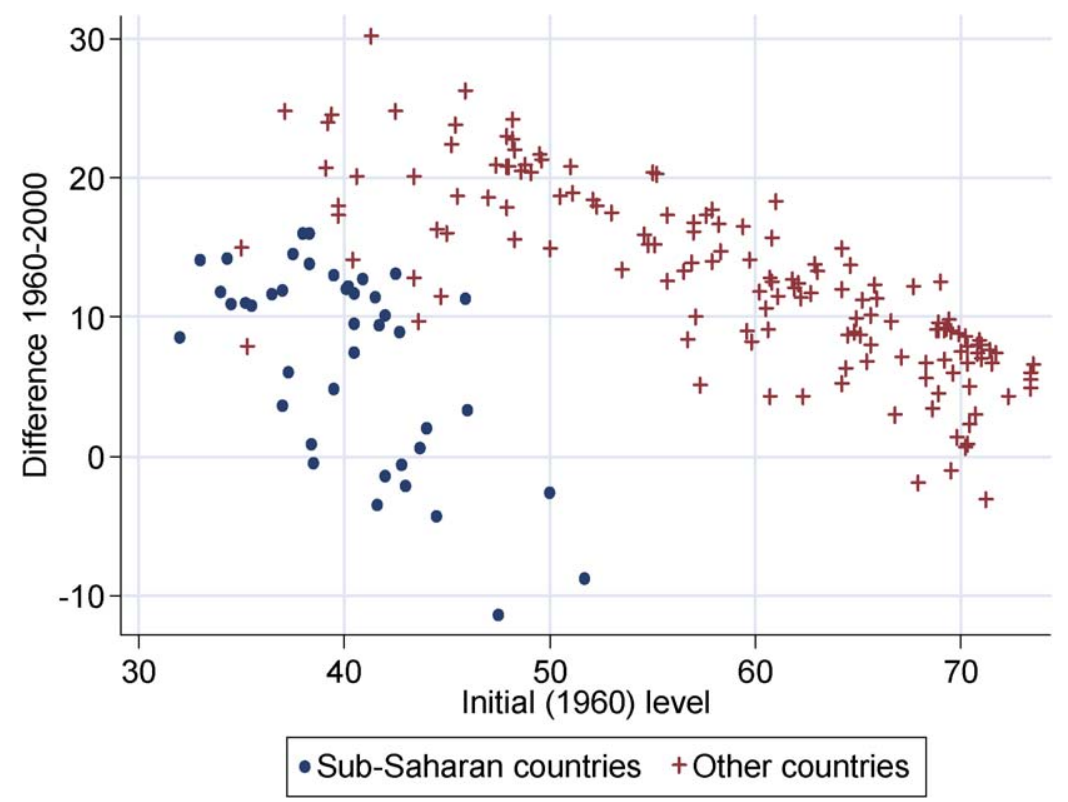

Figure 4. Life expectancy at birth in 1960 and differences between 1960 and 2000.

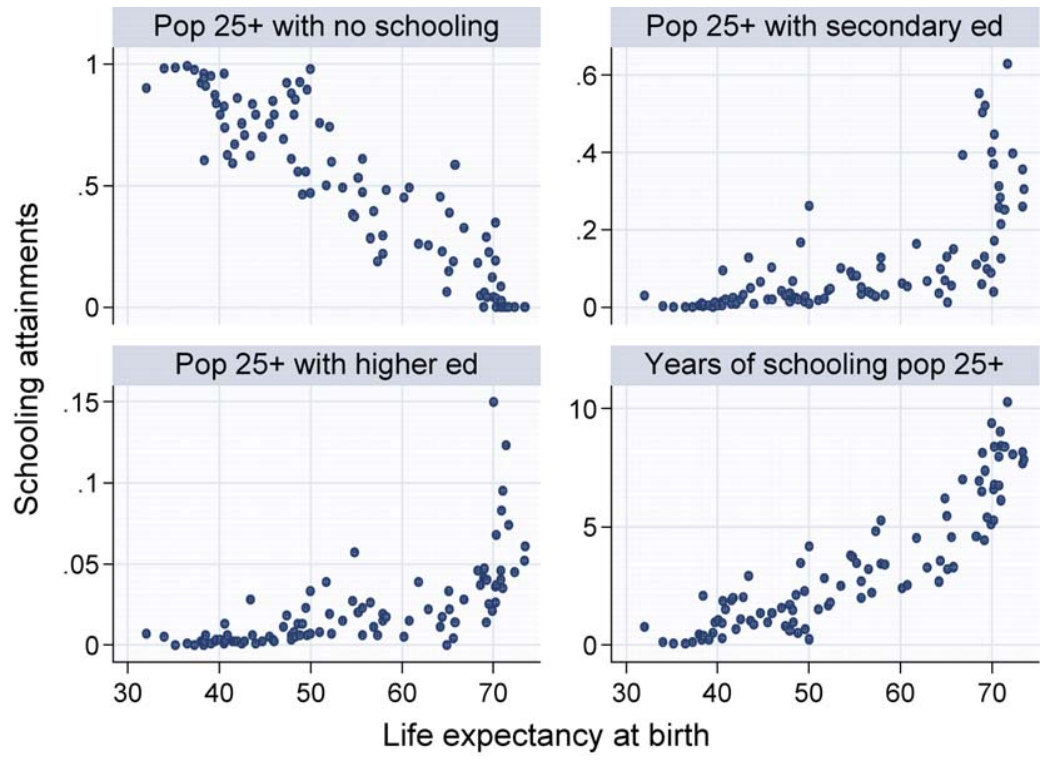

Figure 5. Schooling attainments and life expectancy at birth by country, 1960. 


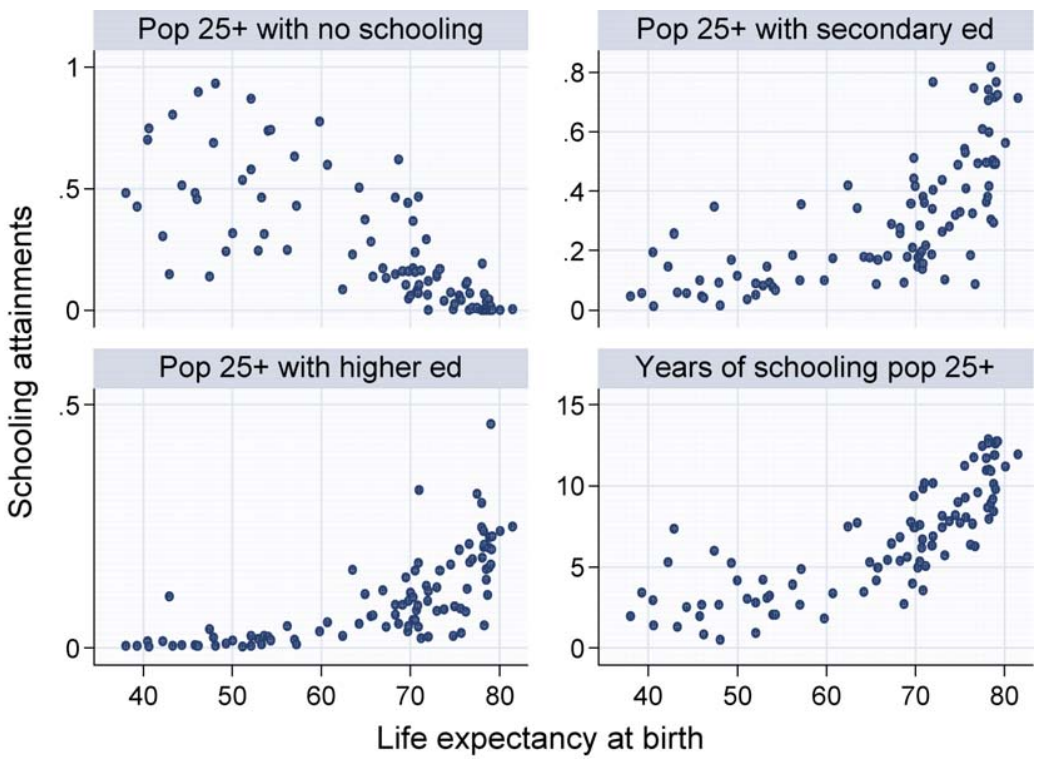

Figure 6. Schooling attainments and life expectancy at birth by country, 2000.

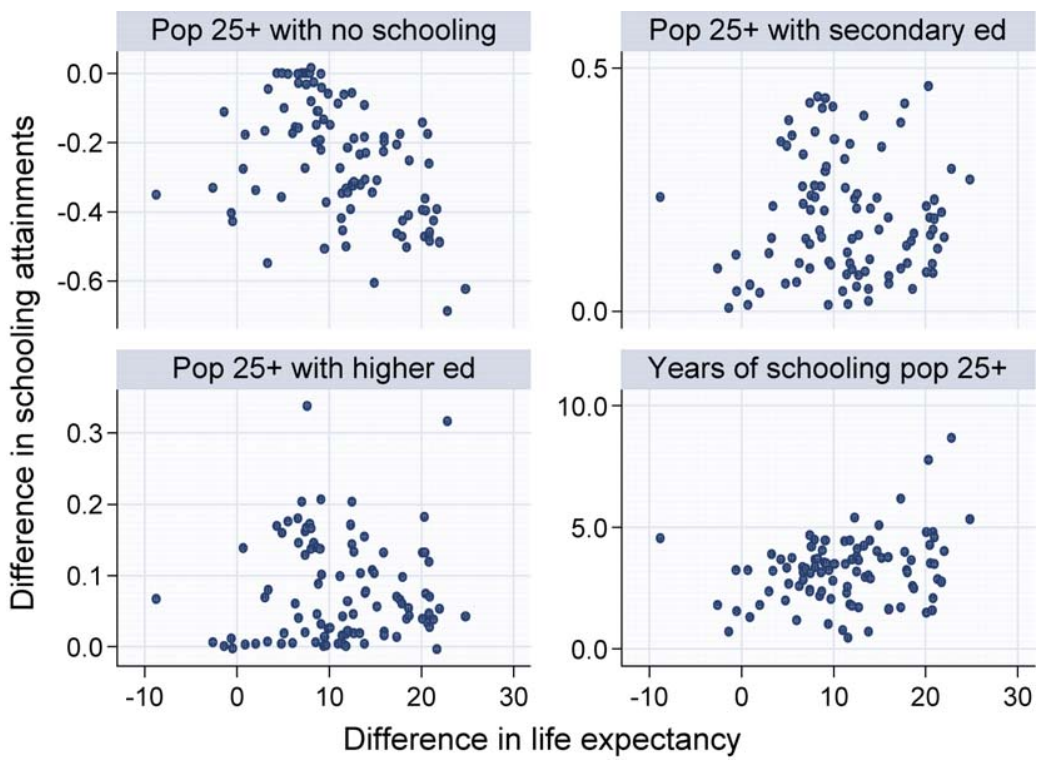

Figure 7. Differences in schooling attainments and differences in life expectancy at birth by country, 1960-2000. 
increase in educational attainments. He argues that "changes have occurred to prevent the decline in returns to acquiring education that would normally accompany a rise in average educational levels. Presumably, these changes have resulted in growth in demand for the investment good, education, sufficient to absorb the increased supply with constant or rising returns". Among the possible explanations, he singles out the "changing composition of industrial activity" and the fact that "technical change may not be neutral between skill-classes" defined by years of education and age or labor market experience.

In the very short-run, the supply of skills and labor market institutions may be treated as given. With exogenous variation in the demand of skills, standard theory predicts that the wage premium should vary inversely with the relative supply of skills. If labor market institutions prevent the wage premium from increasing, the consequence of an increased demand for skills is relative unemployment of the unskilled.

A simple generalization of this partial equilibrium story allows both supply and demand for skills to grow exogenously. In the absence of institutional constraints, now the wage premium goes up or down depending on whether demand grows faster than supply, or vice versa. To keep the wage premium constant, supply and demand must grow at the same rate. In this case, two alternative explanations may be offered for an increase in both the skill premium and the relative employment of the skilled. According to the first, the supply of skills grows at a constant rate but demand accelerates. According to the second, the demand for skills grows at a constant rate but supply decelerates. In either case, the model may be further enriched by allowing labor market institutions to affect the way in which wage premia respond to market forces.

Changes in the growth rate of the supply of skills may depend on changes in cohort size, immigration, educational policies, etc. On the other hand, the three main hypotheses for an acceleration in the growth of the demand for skills are: (i) changes in the organization of production (de-industrialization, that is, the shift from manufacturing to services), (ii) globalization (increased trade, especially with less-skilled countries), and (iii) skill-biased technical change.

The skill-biased technical change (SBTC) hypothesis posits that increases in the relative demand of skills are mainly caused by bursts of new technology, such as the "computer revolution" of the 1980s and 1990s. ${ }^{23}$ As pointed out by Acemoglu (2002a), one problem with the SBTC hypothesis is that it does not provide an explanation of why technical change seems to be skill-biased in certain periods but not in others. For example, during the nineteenth and early twentieth centuries, "the technical change was 'deskilling' - a major purpose of technical change was to expand the division of labor and simplify tasks previously performed by artisans by breaking them into smaller, less skill-requiring pieces" [Acemoglu (2002a, p. 9)]. Card and DiNardo (2002) raise

23 A rather subtle distinction is between technological and organizational changes. For example, Mitchell (2001) argues that changes in the skill premium are connected to the organization of production, as summarized by plant size. When production is organized in large plants, jobs become routinized, favoring less skilled workers. 
another problem, namely the fact that, in the absence of prior information on how different skill groups are affected by changes in technology, "one can always define SBTC to be present whenever changes in relative wages are not inversely related to changes in relative supply".

In the long-run, two things may happen. First, the growth of supply and demand and the changes in the skill premium are jointly determined. If younger cohorts respond to a permanent upward shift in the relative demand for skills by sharply increasing their college enrollment, then SBTC may actually lower the skill premia in the long run. This suggests the possibility of cycles [Freeman (1975a, 1975b, 1986)]: An excess supply of skills due to high levels of investment in the acquisition of skills may depress the skill premia, leading to reduced college enrollment, subsequent excess demand for skills and rising skill premia. This is one of the explanations put forward for the slowdown in the educational attainments of the cohorts born after 1950 in the USA and most European countries and, at the same time, the rise of college premia in the 1980s and 1990s. ${ }^{24}$

Models of this kind have formally been studied only recently. For example, Heckman, Lochner and Taber (1998) develop a heterogenous-agent dynamic general equilibrium model of labor earnings, estimate it using micro data, and use the estimated model to explore the empirical plausibility of alternative explanations for the rise in wage inequality. Azuma and Grossman (2003) develop a model where innovations that increase the relative demand for more educated labor are concomitant with innovations that increase ability premia. The former cause short-run increases in educational premia but long-run offsetting increases in the relative supply of more educated workers. The latter cause a smaller fraction of workers to choose to become more educated and, as a result, cause educational premia to be larger than otherwise.

Second, in the long run, labor market institutions may change in response to shifts in supply and demand. For example, Freeman and Katz (1995) argue in their Introduction that "economic forces that raise relative wages are likely to lead to less centralized collective bargaining or a reduction in union influence on wage setting". At the moment, the study of how labor market institutions respond to pressures brought about by market forces appears to be an open research area.

\subsection{Expectations formations}

In the simple model of Section 3.2, wage premia are assumed to be perfectly known to economic agents when they make their schooling choices. This is a strong assumption, given the variability of wage premia over time. Relaxing this assumption requires answering a number of crucial questions: How do people form their expectations about future wage premia? Are these expectations rational or adaptive? How big is the variability of forecasts? With few exceptions [Siow (1984), Zarkin (1985)], these questions have received little attention in the literature.

24 See, for example, the Introduction to Freeman and Katz (1995) and Card and Lemieux (2001). 
Recently, several authors have tried to shed some light on the way youth perceive the returns to schooling. Betts (1996) uses a survey of 1,269 undergraduates at the University of California, San Diego, to study students' beliefs about salaries by type of education. He finds strong support for the human capital hypothesis that individuals acquire information about earnings by level of education in order to choose their optimal level of education. Information is not perfect, however, and there is evidence of both overestimation of college premia and learning over time.

Dominitz and Manski (1996) report the evidence from a small-scale computerassisted self-administered survey eliciting from high school students and college undergraduates their expected earnings under alternative schooling scenarios, and their beliefs about current earnings distributions. They find substantial within-group variation in earnings expectations and in beliefs about current earnings distribution. Despite this variation, and the fact that respondents appear rather uncertain about their future earnings, there is a common belief that the returns to a college education are positive, that earnings rise between ages 30 and 40. They also find that most respondents overestimate the degree of earnings variability.

Brunello, Lucifora and Winter-Ebmer (2001) report the results of a survey of wage expectations and expected employment probabilities of European college students. The survey, the first of this type in Europe, collected data on over 6,829 college undergraduates from 50 university faculties belonging to 32 universities in 10 European countries. Students were asked about their expected monthly earnings in the following contingencies: (i) starting earnings after college graduation, (ii) starting earnings with only a high-school degree, (iii) college earnings 10 years after graduation, and (iv) high-school earnings 10 years after high-school degree. For students enrolled in business and economics, these subjective expectations were then compared to estimated earnings from a standard human capital earnings function. Consistent with the results in Betts (1996) for the USA, the paper finds that expected college premia are higher than average actual premia.

This result, which apparently lends support to the view that students tend to be too optimistic, is not so clearly interpretable. First, the study compares the expectations of business and economics students, that may have better job prospects, with the actual college premia of all students. Further, since expected monthly wage gains are compared with actual hourly wage gains, the result may simply reflect the fact that college graduates work longer hours than high school graduates.

\section{Wage premia: Empirical evidence}

In this section, I look at the available evidence on movements in wage premia over the last 2-3 decades, focusing on differences in time trends across countries. If countryspecific idiosyncrasies, such as differences in educational systems, income measures, data collection procedures, etc., remain relatively constant through time, then crosscountry comparisons of time trends in educational premia are likely to be easier than 
point in time comparisons. On the other hand, as noted by Gottschalk and Smeeding (1997), "if data quality changes over time, if income components that are less (or more) well reported increase in significance over time, or if factors such as top coding have different impacts over time, then trends as well as levels will be affected".

Most of the available information is for developed countries and covers, at best, the last 2 or 3 decades. The USA is the country for which more is known. The evidence for the USA, mainly based on the micro data from the March Annual Demographic File or the Outgoing Rotation Groups of the CPS, has been summarized by several authors. ${ }^{25}$ It shows large increases in earnings differentials both between workers with different schooling levels (and also with different ages or years of potential labor market experience) and within workers with the same observable characteristics. More precisely, the college wage premium for full-time full-year workers declined substantially during the 1970s, increased sharply during the 1980s, and continued to rise, albeit much more modestly, through most of the 1990s. The returns to experience also increased, especially among the less educated. The results of these trends has been a substantial decline in the relative position of young workers with no college education.

Although institutional changes, namely the weakening of labor unions and the decline of the minimum wage in real terms, may have played a role, "the fact that the skill intensity increased at the same time as the skill premium increased presents a prima facie case for the importance of demand shifts" [Gottschalk and Smeeding (1997, p. 647)]. The prominent demand side explanations are skill-biased technical change, the effects of trade liberalization, and shifts in derived demand for skilled labor resulting from shifts in the composition of final demand. The effects of demand shifts may have been amplified by a relative shortage of skilled labor due to the cohort-size effects and the slowdown of college enrollment, especially among men. Overall, the available evidence appears insufficient to discriminate between these different hypotheses (also because they are not mutually exclusive), thus providing an important motivation for the interest in other countries' experience.

\subsection{Single-country studies}

Single-country studies (including pairwise comparisons with the USA) typically provide important details on the countries being studied. Contrasting their results can be difficult, however, because of the differences in the educational systems, the time periods considered, the nature and quality of the data, etc.

\section{Developed economies}

Developed economies represent the ideal comparison group for analyzing the US experience because of the similarity of economic, social and political fundamentals, the

25 See, for example, Bound and Johnson (1992), Levy and Murnane (1992), Juhn, Murphy and Pierce (1993), Gottschalk (1997), Gottschalk and Smeeding (1997), Katz and Autor (1999), Welch (1999), Card and DiNardo (2002), and Chapter 6 by Don Deere and Jelena Vesovic in this Handbook. 
availability of micro-data of comparable content and quality, and the large institutional differences in the way educational systems are organized and administered.

Most studies summarized in Table 3 report increases in the educational premia, especially after the mid 1980s, despite the rising educational attainments of the population. The standard interpretation is demand rising faster than supply. In a few countries, large increases in the supply of workers with secondary and tertiary education may have contributed to keep the educational premia stable (Ireland, Norway) or may have led to a decline (Austria, Canada, Spain). Institutional settings (wage bargaining rules, employment protection legislation, etc.) may in some cases (Germany, Italy) have partly or even fully offset the influence of market forces.

Some authors place a special emphasis on the role of labor market institutions. For example, Freeman and Katz (1995) argue in their Introduction that "since developed economies operate in the same world markets with similar technologies, ..., changes in demand move in broadly similar ways across countries. Supply changes will diverge more because different countries expanded their higher education systems at different times, but, even so, the proportion of the workforce that is highly educated has risen in all advanced countries. Differences in the pattern of change in supply and demand are thus unlikely be themselves to explain cross-country variation in changes in wage inequality fully". Because of this, they identify "country differences in wage-setting and other labor market institutions ... as an additional determinant of differing patterns of change in inequality".

\section{Transition economies}

The transition process from planned to market economies in Eastern and Central Europe involved dramatic changes in political and economic structures, including labor market institutions. Theoretically, this transition could lead to either increases or decreases in skill premia. For example, if communist ideology overvalued low-skilled blue-collar workers relative to well-educated intellectuals (as is sometimes argued), then returns to education would be lower than in market economies and should therefore increase during the transition. On the other hand, if skills learned under communism are not useful in a market economy, then returns to experience or to pre-transition schooling might actually fall.

In fact, Krueger and Pischke (1995) find that in the late 1980s, just before German reunification, the return to a year of schooling was about the same in East and West Germany. Because higher education took longer in West Germany than in the East, "the higher returns to these degrees in the West are just due to longer schooling, not to higher returns per year of schooling".

Katz (1999) points out that "there are striking similarities in how the productivity of labor and its determinants have been conceptualized in the Soviet wage theory and Western 'human capital' theory". Using a random sample of 1,200 households interviewed in 1989 in Taganrog, a medium-size city located in the South of Russia and dominated by heavy industry, she finds that educational premia are "at the lower end 
Table 3

Educational wage premia. Single country studies: Developed economies

\begin{tabular}{|c|c|c|c|c|}
\hline Country & Reference & Data set & Years & Main findings \\
\hline Australia & $\begin{array}{l}\text { Gregory and Vella } \\
(1995)\end{array}$ & $\begin{array}{l}\text { Labor Force Sur- } \\
\text { vey }\end{array}$ & 1976-90 & $\begin{array}{l}\text { Although the rate of return to } \\
\text { education does not appear to } \\
\text { be increasing, the same change } \\
\text { in earnings dispersion as in the } \\
\text { USA is observed. }\end{array}$ \\
\hline Austria & $\begin{array}{l}\text { Fersterer and Winter- } \\
\text { Ebmer (2003) }\end{array}$ & Microcensus & $1981-97$ & $\begin{array}{l}\text { Falling returns to an additional } \\
\text { year of schooling. }\end{array}$ \\
\hline \multirow[t]{4}{*}{ Canada } & Bar-Or et al. (1995) & $\begin{array}{l}\text { Survey of Con- } \\
\text { sumer Finances } \\
(\mathrm{SCF})\end{array}$ & 1971-1991 & $\begin{array}{l}\text { While there appears to have } \\
\text { been some decline in the return } \\
\text { to university education during } \\
\text { the } 1970 \text { s, the return did not re- } \\
\text { bound much during the } 1980 \mathrm{~s} \\
\text { except for the youngest experi- } \\
\text { ence group. }\end{array}$ \\
\hline & $\begin{array}{l}\text { Beaudry and Green } \\
(2000)\end{array}$ & $\mathrm{SCF}$ & $1971-93$ & $\begin{array}{l}\text { The college wage premium re- } \\
\text { mained constant or fell, but } \\
\text { the dispersion of wage earnings } \\
\text { widened. }\end{array}$ \\
\hline & $\begin{array}{l}\text { Murphy, Riddell and } \\
\text { Romer (1998) }\end{array}$ & $\mathrm{SCF}$ & 1981-94 & $\begin{array}{l}\text { The stability of the college } \\
\text { wage premium is a conse- } \\
\text { quence of the substantial } \\
\text { growth in post-secondary } \\
\text { education. }\end{array}$ \\
\hline & $\begin{array}{l}\text { Burbidge, Magee and } \\
\text { Robb (2001) }\end{array}$ & $\begin{array}{l}\text { SCF, Survey of } \\
\text { Labour Income } \\
\text { Dynamics }\end{array}$ & $1981-99$ & $\begin{array}{l}\text { The college wage premium } \\
\text { has remained stable for men } \\
\text { and has trended downwards for } \\
\text { women. }\end{array}$ \\
\hline \multirow[t]{3}{*}{ Germany } & $\begin{array}{l}\text { Abraham and House- } \\
\text { man (1995) }\end{array}$ & $\begin{array}{l}\text { Survey of } \\
\text { Compensation, } \\
\text { GSOEP }\end{array}$ & 1964-89 & $\begin{array}{l}\text { Relative constancy of differen- } \\
\text { tials across education groups, } \\
\text { stable or narrowing differen- } \\
\text { tials by age group. }\end{array}$ \\
\hline & $\begin{array}{l}\text { Freeman and Schet- } \\
\text { tkat }(2000 \mathrm{a}, 2000 \mathrm{~b})\end{array}$ & & & \\
\hline & $\begin{array}{l}\text { Beaudry and Green } \\
(2003)\end{array}$ & GSOEP & 1979-95 & $\begin{array}{l}\text { "Stable education-wage differ- } \\
\text { ences with rises in real wages } \\
\text { for most workers". }\end{array}$ \\
\hline Ireland & $\begin{array}{l}\text { Barrett, Fitzgerald } \\
\text { and Nolan (2002) }\end{array}$ & $\begin{array}{l}1987 \text { ESRI } \\
\text { survey, } 1994 \text { and } \\
1997 \text { ECHP }\end{array}$ & $\begin{array}{l}\text { 1987, 1994, } \\
1997\end{array}$ & $\begin{array}{l}\text { Increase in returns to univer- } \\
\text { sity education for the middle } \\
\text { or older age groups between } \\
1987 \text { and } 1994 \text {, but not be- } \\
\text { tween } 1994 \text { and } 1997 \text {. }\end{array}$ \\
\hline
\end{tabular}


Table 3

(Continued)

\begin{tabular}{|c|c|c|c|c|}
\hline Country & Reference & Data set & Years & Main findings \\
\hline Israel & Weisberg (1995) & $\begin{array}{l}1974 \text { Labor } \\
\text { Mobility Survey, } \\
20 \% \text { sample of } \\
\text { the } 1983 \text { Census }\end{array}$ & 1974,1983 & $\begin{array}{l}\text { Increase of the educational pre- } \\
\text { mia for all age groups. }\end{array}$ \\
\hline \multirow[t]{2}{*}{ Italy } & $\begin{array}{l}\text { Erickson and Ichino } \\
\text { (1995) }\end{array}$ & SHIW & $1978-87$ & $\begin{array}{l}\text { Weak trend towards lower re- } \\
\text { turns to secondary education } \\
\text { (relative to primary) and higher } \\
\text { returns to college. }\end{array}$ \\
\hline & $\begin{array}{l}\text { Casavola, Gavosto } \\
\text { and Sestito (1996) }\end{array}$ & $\begin{array}{l}\text { Administrative } \\
\text { data from Social } \\
\text { Security }\end{array}$ & $1986-90$ & $\begin{array}{l}\text { Weak evidence of increasing } \\
\text { wage premia for white-collar } \\
\text { jobs. }\end{array}$ \\
\hline Netherlands & $\begin{array}{l}\text { Hartog, Oosterbeek } \\
\text { and Teulings (1993) }\end{array}$ & $\begin{array}{l}\text { Structure of } \\
\text { Earnings Survey }\end{array}$ & $1962-89$ & $\begin{array}{l}\text { Returns to education dropped } \\
\text { continuously between } 1962 \\
\text { and } 1985 \text {, while the level of } \\
\text { education of the labor force } \\
\text { increased steadily. After } 1985 \text {, } \\
\text { returns to education stabilized } \\
\text { with no indication of a slow- } \\
\text { down in the rise of educational } \\
\text { attainments. }\end{array}$ \\
\hline \multirow[t]{2}{*}{ Norway } & Kahn (1998) & $\begin{array}{l}\text { Level of Living } \\
\text { Survey }\end{array}$ & 1980-91 & $\begin{array}{l}\text { Stable returns to education, } \\
\text { largely because of the central- } \\
\text { ized wage bargaining process. }\end{array}$ \\
\hline & $\begin{array}{l}\text { Hoegeland, Klette and } \\
\text { Salvanes (1999) }\end{array}$ & $\begin{array}{l}1980 \text { Census, } \\
1990 \text { Survey of } \\
\text { Population and } \\
\text { Housing }\end{array}$ & 1980, 1990 & $\begin{array}{l}\text { Stable returns to education, be- } \\
\text { cause of the increasing supply } \\
\text { of highly educated workers. }\end{array}$ \\
\hline \multirow[t]{2}{*}{ Portugal } & $\begin{array}{l}\text { Machado and Mata } \\
\text { (2001) }\end{array}$ & $\begin{array}{l}\text { Census of firms } \\
\text { and their work- } \\
\text { ers (Quadros de } \\
\text { Pessoal) }\end{array}$ & 1982, 1994 & $\begin{array}{l}\text { Increase in college wages rela- } \\
\text { tive to wages of workers with } \\
\text { only compulsory education. }\end{array}$ \\
\hline & $\begin{array}{l}\text { Hartog, Pereira and } \\
\text { Vieira }(2001)\end{array}$ & $\begin{array}{l}\text { Quadros de Pes- } \\
\text { soal }\end{array}$ & $\begin{array}{l}1982, \quad 1986, \\
1992\end{array}$ & $\begin{array}{l}\text { Returns to education were sta- } \\
\text { ble between } 1982 \text { and } 1986 \text {, } \\
\text { but increased substantially be- } \\
\text { tween } 1986 \text { and } 1992 \text {. }\end{array}$ \\
\hline \multirow[t]{2}{*}{ Spain } & Abadie (1997) & $\begin{array}{l}\text { Family Budget } \\
\text { Survey }\end{array}$ & $\begin{array}{l}1980 / 81 \\
1990 / 91\end{array}$ & $\begin{array}{l}\text { Substantial decline in the ed- } \\
\text { ucational premium, mainly for } \\
\text { young and elderly workers. }\end{array}$ \\
\hline & Vila and Mora (1998) & $\begin{array}{l}\text { Family Budget } \\
\text { Survey }\end{array}$ & $\begin{array}{l}\text { 1980/81 } \\
1990 / 91\end{array}$ & $\begin{array}{l}\text { Falling returns to primary and } \\
\text { lower secondary education, } \\
\text { stable or increasing returns to } \\
\text { higher education. }\end{array}$ \\
\hline
\end{tabular}


Table 3

(Continued)

\begin{tabular}{|c|c|c|c|c|}
\hline Country & Reference & Data set & Years & Main findings \\
\hline Sweden & $\begin{array}{l}\text { Edin and Holmlund } \\
\text { (1995) }\end{array}$ & $\begin{array}{l}\text { Level of Living } \\
\text { Survey, HUS }\end{array}$ & 1968-91 & $\begin{array}{l}\text { Wage differentials shrank } \\
\text { from the mid-1960s up to } \\
\text { the early 1980s, and then } \\
\text { widened from the mid-1980s. } \\
\text { Returns to schooling and } \\
\text { experience fell during the first } \\
\text { period, and increased during } \\
\text { the second. Argue that "a } \\
\text { simple demand and supply } \\
\text { framework can account for } \\
\text { movements in educational } \\
\text { wage differentials". }\end{array}$ \\
\hline \multirow[t]{2}{*}{ UK } & $\begin{array}{l}\text { Harmon and Walker } \\
\text { (1995) }\end{array}$ & $\begin{array}{ll}\text { Family } & \text { Expen- } \\
\text { diture } & \text { Survey } \\
\text { (FES) } & \end{array}$ & $1978-86$ & $\begin{array}{l}\text { No evidence of time trends in } \\
\text { the returns to education. }\end{array}$ \\
\hline & Schmitt (1995) & $\begin{array}{l}\text { General House- } \\
\text { hold Survey } \\
\text { (GHS) }\end{array}$ & $1974-88$ & $\begin{array}{l}\text { U-shaped pattern of educa- } \\
\text { tional premia for high- and } \\
\text { mid-level qualifications, with } \\
\text { the gains over the } 1980 \text { s offset- } \\
\text { ting the decline during the late } \\
\text { 1970s. }\end{array}$ \\
\hline
\end{tabular}

of an international spectrum, but not extreme". She argues that in order to explain these relatively lower (but not extremely low) returns, no assumption of ideologically motivated bias is necessary. "One thing that the USSR did achieve was wide access to education, for women as well as for men. With a large supply of educated and skilled labor, market forces were exerting a downward pressure on returns to schooling."

Svejnar (1988) summarizes the studies that investigate the changes in the returns to education during the earlier stages of the transition to a market economy. In general, these studies find increases in the returns to schooling and greater incentives to human capital investments, especially among men.

Rutkowski (2001) updates the results of several earlier papers on the structure of earnings in Central Europe (CE), including the Baltic states but excluding the countries of the former Soviet Union. He argues that "returns to education have considerably increased in all transition economies of CE (for which the relevant data are available) and now by and large they are comparable to those observed in advanced market economies. [...] Especially strong was the increase in the university earnings premium, while the premium to secondary education increased much more modestly". Table 4 summarizes a few other recent studies. 
Table 4

Educational wage premia. Single country studies: Transition economies

\begin{tabular}{|c|c|c|c|c|}
\hline Country & Reference & Data set & Years & Main findings \\
\hline $\begin{array}{l}\text { Czech Repub- } \\
\text { lic }\end{array}$ & $\begin{array}{l}\text { Filer, Jurajda and } \\
\text { Plánovský (1999) }\end{array}$ & $\begin{array}{l}1988 \text { Microcen- } \\
\text { sus, } 1996 \text { Survey } \\
\text { of Economic Ex- } \\
\text { pectations and } \\
\text { Attitudes }\end{array}$ & 1988,1996 & $\begin{array}{l}\text { Rapidly rising returns to } \\
\text { schooling rose during the } \\
\text { transition to a market econ- } \\
\text { omy. By the mid-1990s, they } \\
\text { approximated those found in } \\
\text { many market economies. It is } \\
\text { argued that the driving force } \\
\text { behind this process initially } \\
\text { was the reallocation of eco- } \\
\text { nomic activity between sectors } \\
\text { but, after 1992, it was the rapid } \\
\text { growth of the private sector. } \\
\text { Confirm the results in Flanagan } \\
\text { (1998), but with much larger } \\
\text { increases in the return to } \\
\text { education. }\end{array}$ \\
\hline
\end{tabular}

Poland Keane and Prasad Household Bud- 1985-96 Educational premia rose (2002) get Survey rapidly during the transition, whereas the premium for labor market experience declined in the early years of transition and the position of older workers deteriorated relative to younger workers.

\section{Developing economies}

During the last 30 years, developing economies have been characterized by substantial increases in the educational attainments of the population and the workforce. At the same time, changes in the industrial structure in response to economy-wide reforms (privatizations, liberalizations, tax reforms, labor market reforms, etc.) have altered the demand for labor. Hence, these economies represent ideal cases for studying the relative importance of supply and demand factors on the structure of earnings. Unfortunately, this task is not easy, mainly because of problems of data availability and quality.

An important difference between developed and developing economies is the fact that employees outnumber the self-employed in the former, while the opposite is often true in the latter. The importance of self-employment in developing economies (and in some developed economies as well) raises both problems of self-selection (why do people choose to be self-employment?) and unresolved issues of how income and work effort should be measured. Further, whenever the employees are a relatively small fraction of the workforce, they also tend to be disproportionately concentrated in the public 
sector where, because of the way wages are set, the link between educational premia and worker productivity tends to be weaker.

Table 5 summarizes some recent studies. While coverage of Latin American countries is good, much less is known for African and Asian countries. Notice that the experience of workers in most African countries has been different from those in developed economies and other developing countries, as real wages fell substantially between the early 1970s and the 1990s. Latin American countries have instead been characterized by a process of trade liberalization and economy-wide reforms.

Several studies focus on the impact of the Mexican trade liberalization of 19851987 on the wage structure. All these studies find an increase in the skill premium, but offer different (not necessarily mutually exclusive) explanations. Hanson and Harrison (1995) argue that the rising skill premium is associated to changes internal to industries, or even internal to plants. Revenga (1995) instead argues that it reflects the fact that production (low-skilled) workers are more concentrated in industries that experienced a larger decline in tariffs protection. Cragg and Epelbaum (1996) relate the increase in the skill premium to a rise in the demand of more educated workers resulting from capital-skill complementarity. López-Acevedo (2001) takes a broader look at the effects of Mexico's structural changes on earnings inequality. She argues that "there was a shift in demand towards high-skilled labor that was not met by an increase in supply. This probably occurred as a result of the rapid rate of skill-biased technological change, whose transmission to Mexico was facilitated by the economy's increased openness".

\subsection{Multi-country studies}

Starting from the mid 1990s, increasing attention has been devoted to multi-country studies. As emphasized by Davis (1992), the importance of multi-country study is threefold: (i) "they represent a powerful tool for discriminating among competing explanations and for identifying the causal component of institutional changes and government interventions", (ii) "they serve as useful inputs into detailed studies on individual countries by suggesting when to pursue explanations that stress factors common to many countries and when to pursue explanations that stress country-specific factors", (iii) "they are likely to highlight certain hypotheses or suggest additional explanations that fail to surface in studies on particular countries".

One hypothesis that has received considerable attention is a description of US and European labor markets during the 1970s and 1980s that goes roughly as follows. There has been a substantial increase in the relative demand for skills, possibly driven by pervasive SBTC. ${ }^{26}$ In countries where wages are flexible (UK, USA), this generated substantial increases in skill premia (decline in the relative wages of the unskilled). In countries where wages are rigid (continental Europe), the consequence was instead a large rise of unemployment among the unskilled (young or low educated workers).

26 Berman, Bound and Machin (1998) find that SBTC during the 1970s and 1980s was "pervasive throughout the developed world". 
Table 5

Educational wage premia. Single country studies: Developing economies

\begin{tabular}{lllll}
\hline Country & Reference & Data set & Years & Main findings \\
\hline Africa & Teal (2000) & Panel of firms & $1991-95$ & $\begin{array}{l}\text { As average earnings fell, their } \\
\text { dispersion widened, with the } \\
\text { lowest paid experiencing the } \\
\text { Ghana }\end{array}$ \\
& $\begin{array}{l}\text { Skyt Nielsen } \\
\text { Rosholm (2001) }\end{array}$ & and & $\begin{array}{l}\text { Household Sur- } \\
\text { vey }\end{array}$ & $1991, \quad 1993, \begin{array}{l}\text { Average real wages declined } \\
\text { steadily during the period con- } \\
\text { sidered. }\end{array}$ \\
\hline
\end{tabular}

Asia

\begin{tabular}{|c|c|c|c|c|}
\hline India & Duraisamy (2002) & $\begin{array}{l}\text { National Sample } \\
\text { Survey }\end{array}$ & $\begin{array}{l}1983, \\
1993 / 94\end{array}$ & $\begin{array}{l}\text { While returns to upper sec- } \\
\text { ondary and college education } \\
\text { changed little, returns to pri- } \\
\text { mary and lower secondary ed- } \\
\text { ucation declined and those } \\
\text { to technical diploma/certificate } \\
\text { increased substantially. }\end{array}$ \\
\hline Korea & Kim and Topel (1995) & $\begin{array}{l}\text { Occupational } \\
\text { Wage Survey }\end{array}$ & $1971-89$ & $\begin{array}{l}\text { Huge drop in the college pre- } \\
\text { mium due to an exceptionally } \\
\text { fast growth in the share of the } \\
\text { workforce with a college de- } \\
\text { gree. }\end{array}$ \\
\hline
\end{tabular}

Latin America

\begin{tabular}{lll}
\hline Brazil & $\begin{array}{l}\text { Blom, Holm-Nielsen } \\
\text { and Verner (2001) }\end{array}$ & $\begin{array}{l}\text { Monthly Labor } \\
\text { Force Survey }\end{array}$
\end{tabular}

Substantial increases in the educational attainments of the Brazilian workforce, the largest expansion being for the intermediate education levels. Tertiary education increased significantly during the 1980s, but slowed down during the 1990s. During the same period, returns to tertiary education increased sharply, while returns to primary and secondary education dropped substantially.

Ferreira (2002) Nationwide 1976-98

Household

Sustantial increases in the col-

Sample lege wage premium despite a significant increase in the relative supply of male workers with a college degree. 
Table 5

(Continued)

\begin{tabular}{|c|c|c|c|c|}
\hline Country & Reference & Data set & Years & Main findings \\
\hline Chile & Montenegro (2001) & $\begin{array}{l}\text { National Socioe- } \\
\text { conomic Survey } \\
\text { (CASEN) }\end{array}$ & 1990-98 & $\begin{array}{l}\text { Stability of returns to education } \\
\text { during the period considered. } \\
\text { Returns to education increase } \\
\text { moving from the lower to the } \\
\text { upper part of the wage distrib- } \\
\text { ution. Women have higher re- } \\
\text { turns to education than men in } \\
\text { the lower part of the wage dis- } \\
\text { tribution, and similar returns in } \\
\text { the upper part. }\end{array}$ \\
\hline Colombia & $\begin{array}{l}\text { Cárdenas and Bernal } \\
\text { (1999) }\end{array}$ & $\begin{array}{l}\text { quarterly House- } \\
\text { hold Survey and } \\
\text { annual Manufac- } \\
\text { turing Survey }\end{array}$ & 1974-96 & $\begin{array}{l}\text { Decrease of the college wage } \\
\text { premium between } 1976 \text { and } \\
1981 \text { attributed to the increase } \\
\text { in the relative supply of more } \\
\text { educated workers. The post- } \\
1991 \text { increase is attributed to } \\
\text { the rapid increase in their rel- } \\
\text { ative demand fostered by struc- } \\
\text { tural economic reforms. }\end{array}$ \\
\hline Costarica & Funkhouser (1998) & $\begin{array}{l}\text { National Survey } \\
\text { of Households, } \\
\text { Employment } \\
\text { and Unemploy- } \\
\text { ment }\end{array}$ & 1976-92 & $\begin{array}{l}\text { Returns to education fell by } \\
\text { about one fourth between } 1977 \\
\text { and 1983, followed by a slight } \\
\text { rebound after } 1983 \text {. This be- } \\
\text { havior appears to be negatively } \\
\text { correlated with measures of } \\
\text { supply of education and posi- } \\
\text { tively correlated with measures } \\
\text { of demand. }\end{array}$ \\
\hline \multirow[t]{2}{*}{ Mexico } & $\begin{array}{l}\text { Hanson and Harrison } \\
\text { (1995) }\end{array}$ & $\begin{array}{l}\text { plant level } \\
\text { data (Annual } \\
\text { Manufacturing } \\
\text { Survey) }\end{array}$ & & $\begin{array}{l}\text { Increases in the skill premium, } \\
\text { but little changes in relative } \\
\text { employment. They argue that } \\
\text { the rising skill premium is as- } \\
\text { sociated to changes internal to } \\
\text { industries, or even internal to } \\
\text { plants. }\end{array}$ \\
\hline & Revenga (1995) & $\begin{array}{l}\text { Annual Manu- } \\
\text { facturing Survey }\end{array}$ & & $\begin{array}{l}\text { Increases in the skill premium, } \\
\text { attributed to the fact that pro- } \\
\text { duction (low-skilled) workers } \\
\text { are more concentrated in indus- } \\
\text { tries that experienced a larger } \\
\text { decline in tariffs protection. }\end{array}$ \\
\hline
\end{tabular}

(Continued on next page) 
Table 5

(Continued)

\begin{tabular}{|c|c|c|c|c|}
\hline Country & Reference & Data set & Years & Main findings \\
\hline & $\begin{array}{l}\text { Cragg and Epelbaum } \\
\text { (1996) }\end{array}$ & $\begin{array}{l}\text { Urban Employ- } \\
\text { ment Survey }\end{array}$ & 1987-93 & $\begin{array}{l}\text { Increases in the skill premium, } \\
\text { attributed to a rise in the de- } \\
\text { mand of more educated work- } \\
\text { ers resulting from capital-skill } \\
\text { complementarity. }\end{array}$ \\
\hline & $\begin{array}{l}\text { López-Acevedo } \\
\text { (2001) }\end{array}$ & $\begin{array}{l}\text { Urban Employ- } \\
\text { ment Survey, } \\
\text { Household } \\
\text { Income and } \\
\text { Expenditure } \\
\text { Survey }\end{array}$ & 1987-98 & $\begin{array}{l}\text { She argues that "there was a } \\
\text { shift in demand towards high- } \\
\text { skilled labor that was not met } \\
\text { by an increase in supply. This } \\
\text { probably occurred as a result } \\
\text { of the rapid rate of skill-biased } \\
\text { technological change, whose } \\
\text { transmission to Mexico was fa- } \\
\text { cilitated by the economy's in- } \\
\text { creased openness". }\end{array}$ \\
\hline Uruguay & $\begin{array}{l}\text { Gonzáles and Miles } \\
\text { (2001) }\end{array}$ & $\begin{array}{l}\text { Household Sur- } \\
\text { vey }\end{array}$ & 1986-97 & $\begin{array}{l}\text { Returns to college education } \\
\text { increased significantly while } \\
\text { returns to primary education } \\
\text { diminished at basically every } \\
\text { quantile. During the same pe- } \\
\text { riod, wage bargaining moved } \\
\text { from a completely centralized } \\
\text { process towards a more decen- } \\
\text { tralized system. }\end{array}$ \\
\hline
\end{tabular}

Davis (1992) summarizes a variety of heterogeneous information on 9 developed countries $^{27}$ and 4 developing countries ${ }^{28}$ for the 1970 s and the 1980s. He finds that education differentials fell sharply for developed countries during the 1970s, and became flat or rising during the 1980s. The USA is the only developed country to show a net increase in the college wage premium over the two decades as a whole.

Nickell and Bell (1996) compare Germany, UK and the USA during the 1970s and 1980s. They observe that "in most European countries there has been a significant increase in skilled unemployment as well as in unskilled unemployment". Further, "the relative wages of the unskilled have not fallen in Germany but have fallen substantially in Britain and the United States". As an explanation, they suggest the fact that "education and training levels in the bottom half of the ability range are far higher in Germany than in Britain or the United States".

27 Australia, Canada, France, Germany, Japan, Netherlands, Sweden, UK and USA.

28 Brazil, Colombia, South Korea, and Venezuela. 
Card and Lemieux (2001) compare Canada, the UK and the USA. The US data cover the period 1959-1996 and are drawn from the 1960 census and the March CPS from 1970 to 1997 . The UK data cover the period 1974-1996 and are drawn from the General Household Survey. The data for Canada cover the period 1981-1996 and are drawn from the 1981, 1986, 1991 and 1996 Censuses. Their earnings measure is log weekly wages of full-time male workers aged 26 to 60 . They show that, in all three countries, the college/high school wage gap has increased for younger men, but has remained nearly constant for older men. They explain the shift in the age structure of the wage premium with intercohort shifts in the relative supply of highly educated workers driven by the slowdown in the growth of educational attainments that began with the cohorts born in the early 1950 s.

Some recent multi-country studies focus in more detail on the countries of Western Europe. Brunello, Comi and Lucifora (2000) compare the differences in the male college wage gap (both the college-high school wage gap and the college-less than college wage gap) in 10 European countries $^{29}$ for two cohorts (people born in 1940-49 and 1950-59). The original data were drawn from individual micro surveys and collapsed into cohort data. Their earnings measure is average hourly wages before taxes (after taxes in Austria and Italy) of full-time employees. They find evidence of significant differences, both across countries and across cohorts, in the level and growth of the college wage gap. In some countries the college wage gap increased over the period (Denmark, Finland, Italy, Portugal, Switzerland, UK), while in other countries it did not change (France, Germany, Netherlands) or even declined (Austria). Estimated growth appears to be negatively correlated to changes in relative supply and positively correlated both to an index of between-industries demand shocks and to the long-run rate of labor productivity growth. Institutional changes also appear to matter, as countries that have experienced a decline in union density, centralization of the wage bargain, and employment protection have also had a faster growth in the college wage gap.

The volume edited by Harmon, Walker and Westergaard-Nielsen (2001) collects the results of a research project entitled Public Funding and Private Returns to Education (PURE), whose main objective was to estimate the returns to education for 15 European countries. ${ }^{30}$ Early versions of each country report were published in Asplund and Pereira (1999). Each country team estimated Mincerian returns to education, separately for men and women, using the available cross-sectional data for the period from the mid-1975 to the mid-1995. A variety of checks were carried out to study the robustness of the results to model specification. ${ }^{31}$

\footnotetext{
29 Austria, Denmark, Finland, France, West Germany, Italy, Netherlands, Portugal, Switzerland and the UK. 30 Austria, Denmark, Finland, France, Germany, Greece, Ireland, Italy, Netherlands, Portugal, Spain, Sweden, Switzerland and UK.

31 Potential experience versus age, ordinary least squares versus instrumental variables and quantile regressions, returns to different subgroups of the population, sensitivity to the choice of the other right-hand side variables, sensitivity to the inclusion of corrections for sample selection, etc.
} 


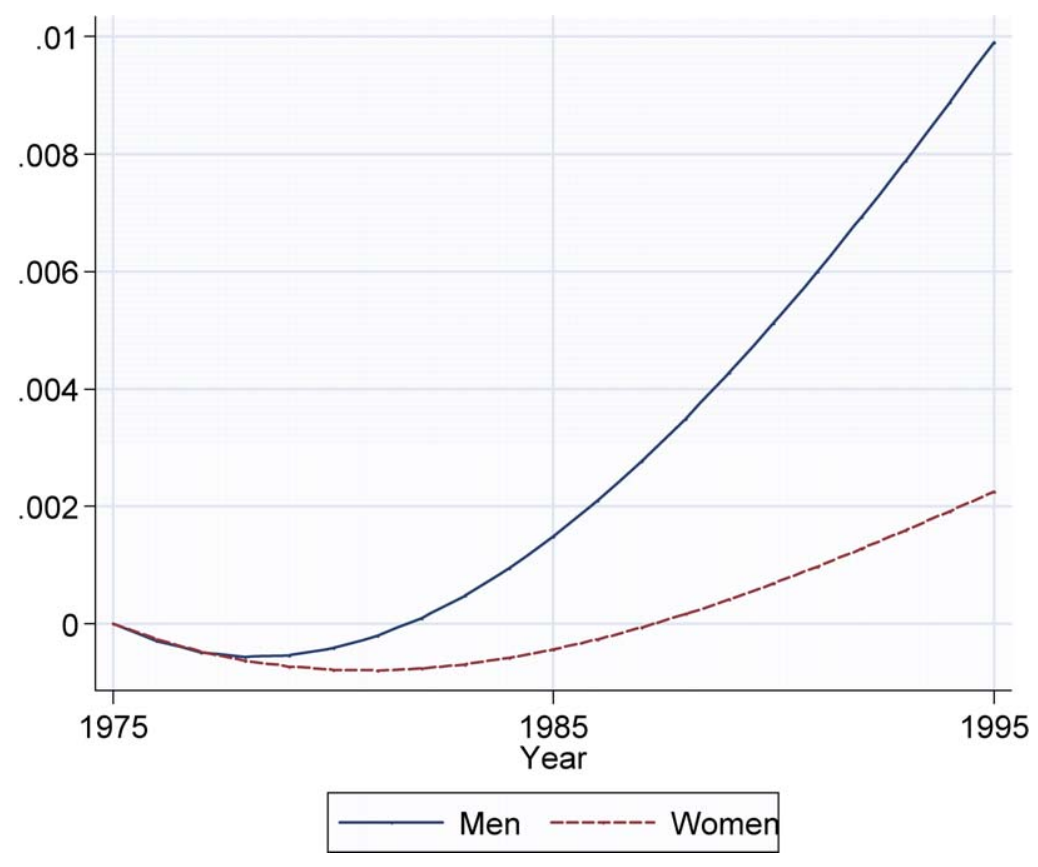

Figure 8. Average time-profile of the returns to schooling by sex in the 15 countries of the PURE project.

Figure 8 summarizes the results of the project. It presents the average time profiles of Mincerian returns to an extra year of schooling, taking 1975 as the baseline, separately for men and women. The two profiles have been obtained by using a regression model with a cubic time trend and a set of country dummies to fit the returns estimated by the various country team for each available year between 1975 and 1995. Qualitatively, the two profiles are very similar. They fall until the late 1970 s or early 1980 s, and rise afterwards. For men, the decline stops earlier and the subsequent rise is faster than for women, with an average gain of about 1 percentage point between 1980 and 1995 .

Behavior across European countries differs widely. Table 6, corresponding to Table 1.1 in Harmon, Walker and Westergaard-Nielsen (2001), summarizes the relative size of Mincerian returns in the 1980s and the trends between 1975 and 1995, separately for men and women. Returns to schooling decreased in Austria and Sweden, but increased in Denmark, Italy and Portugal. Other countries showed no trend at all (France, Germany, Greece, Ireland, Norway and Switzerland), or different behavior of male and female returns (Finland, Netherlands, Spain and UK).

To my knowledge, only few studies cover developing countries. Davis (1992) looks at the experience of Brazil, Colombia, South Korea and Venezuela during the 1970s and 1980s, and finds sharply declining education differentials during the 1980s. Behrman, Birdsall and Székely (2000) analyze the impact of economy-wide reforms on wage differentials using data for 18 Latin American countries for the period 1980- 
Table 6

Relative size of returns in the 1980s and trends in returns for the countries in the PURE project: + indicates relatively high returns,: indicates relatively low returns, 0 indicates returns close to the average, and indicates no obvious trend

\begin{tabular}{|c|c|c|c|c|}
\hline \multirow[t]{2}{*}{ Country } & \multicolumn{2}{|c|}{ Returns in $1980 \mathrm{~s}$} & \multicolumn{2}{|l|}{ Trend } \\
\hline & Men & Women & Men & Women \\
\hline Austria & + & + & Down & Down \\
\hline Denmark & : & : & Up & Up \\
\hline Finland & + & + & - & Up \\
\hline France & 0 & 0 & - & - \\
\hline Germany & + & + & - & - \\
\hline Greece & : & 0 & - & - \\
\hline Ireland & + & + & $-(\mathrm{Up})$ & - \\
\hline Italy & $:$ & $:$ & Up & $\mathrm{Up}$ \\
\hline Netherlands & $:$ & $:$ & $\mathrm{Up}$ & Down \\
\hline Norway & $:$ & $:$ & - & - \\
\hline Portugal & + & + & $\mathrm{Up}$ & $\mathrm{Up}$ \\
\hline Spain & $:$ & + & - & Up \\
\hline Sweden & : & : & Down & Down \\
\hline Switzerland & + & + & - & - \\
\hline UK & $:$ & + & $\mathrm{Up}$ & - \\
\hline
\end{tabular}

Source: Table 1.1 in Harmon, Walker and Westergaard-Nielsen (2001).

1998. They find that educational premia have increased considerably, especially in the 1990s. Domestic financial market reforms, capital account liberalizations, tax reforms and labor market reforms appear to have had a strong positive effect on wage differentials, but this effect tends to fade away rapidly. Privatizations have a negative effect, whereas trade openness has no overall effect, "perhaps because it triggers many countervailing forces that cancel each other out". Duryea, Jaramillo and Pagés (2002) present estimates of the returns to an extra year of schooling for primary, secondary and tertiary education during the 1990s, obtained from samples of urban males aged 30-50 for several Latin American countries. They show that returns to secondary education fell slightly during the period considered, whereas returns to tertiary education rose.

\subsection{Studies based on harmonized cross-national data}

The patterns emerging from multi-country studies, or from a comparison of singlecountry studies, may be regarded with some skepticism due to the difficulty of making direct comparisons. Recently, greater richness in cross-country studies is possible thanks to the increasing availability of harmonized micro data.

There are two main types of harmonized micro data. The first type consists of data originally collected by national statistical agencies that have been subsequently 
processed in order to produce greater uniformity in cross-national comparisons. Leading examples are the Luxembourg Income Study (LIS) and the Cross-National Equivalent File BHPS-GSOEP-PSID-SLID produced by the Department of Policy Analysis and Management at Cornell University and the German Institute for Economic Research (DIW) in Berlin. As argued by Gottschalk and Joyce (1998), "attempts to make these data sets has costs as well as benefits. The major cost is that we are forced to use the lowest common denominator in defining variables and samples".

The second type consists of data collected for a number of countries using a similar questionnaire and a harmonized survey design. Leading examples are the International Social Survey Programme (ISSP) and the European Community Household Panel (ECHP). These data sets usually come much closer to the ideal of a single survey instrument applied to all countries.

For either type of data, an important question that would deserve more careful consideration is to what extent the efforts to ensure comparability across countries and over time have been successfull. ${ }^{32}$

\section{The LIS}

The LIS is a collection of micro data sets obtained from annual income surveys in several (mainly developed) countries. ${ }^{33}$ The LIS contains a historical database for 5 countries (Canada, Germany, Sweden, UK and USA), covering the period from the late 1960s to the mid 1970s, and 5 waves of data covering the subsequent period at roughly 5 -year intervals. Wave IV, currently the most complete, is centered around 1995 and collects data on 26 countries, of which 20 are European.

Prior to inclusion into the LIS database, each survey goes though a "lissyfication" process that, in principle, should enhance comparability across countries and over time. In fact, comparability remains a problem because, except for a few variables (such as age, marital status and relationship to the household head), definitions and codings are not standardized. Key variables such as earnings, labor force status and education are defined and coded differently in the various countries or over time, with LIS making little attempts at harmonizing them. Further, not all variables listed in the LIS database are available for each country/year. In particular, the early LIS waves contain very limited information on education, usual hours per week, and weeks worked per year. Thus, for example, education is not available for Norway and the UK until 1986, and for Sweden until 1992.

Gottschalk and Joyce (1998) use LIS data from the late 1970s to the early 1990s for 8 countries $^{34}$ to estimate changes in returns to age and education over time and across countries. Their statistical model is a version of model (2), with occupational dummies

32 See Atkinson and Brandolini (2001) for a discussion.

33 See Smeeding, O'Higgins and Rainwater (1990).

34 Australia, Canada, Finland, Israel, Netherlands, Sweden, UK and USA. 
replacing educational dummies in Sweden and the UK. They focus attention on the subsample of male employees aged 25-54 who are heads of household and work fulltime. They find that the increase in the educational premium in the USA between 1979 and 1986 was the largest across all countries. The increase between 1986 and 1991 was also large, but not much larger that what was experienced during the same period by several other countries. Further, for most countries considered, changes in the returns to skill are strongly negatively related to changes in the relative supplies of skills, although the evidence is weaker for the educational premium. They conclude that "market forces can be used to explain much of the cross-national differences that have been attributed in the literature to differences in labor market institutions".

Peracchi (2001) compares the US trends from the March CPS with the evidence for 12 countries in the LIS ${ }^{35}$ over a longer period from the mid 1970s to the mid 1990s, focusing attention on the subsample of full-time (male and female) employees aged 2559. He finds that most of the stylized facts observed for the USA also hold for a large majority of the countries included in the LIS database. Therefore, far from being unique, the US experience appears to be part of a phenomenon that is common to most developed countries. The intensity of the trends does differ across countries, but not their nature.

He finds that educational premia vary considerably across countries, partly reflecting problems of comparability of educational attainments. For the same country, however, they are remarkably similar at different quantiles, indicating that higher education implies a uniform shift to the right in the distribution of earnings. Israel and the USA are among the countries where educational premia are initially highest.

His evidence suggests classifying countries into three groups. The first group (Australia, Finland, Germany, and Norway) contains countries where no increase in the educational premia is observed, neither for men nor for women. The second group (Canada, Poland, and the USA) contains instead countries where all educational premia have increased, both for men and for women. Finally, the third group (Israel, Italy, Netherlands, Taiwan and the UK) contains countries were the patterns are mixed. According to his estimates, the average annual increase in the high-school premium for US males has been the highest among all countries considered, whereas the increase in the college premium in the USA remains below that observed for other countries such as Italy and Poland.

One explanation for some of the differences with respect to the previous literature is the fact that Peracchi (2001) includes the early and mid 1990s, thus capturing an increase in earnings inequality that was not yet present in the data for the 1980s. This raises the interesting, and largely unexplored, question of why the USA has been leading the other developed countries. The issue of timing may further help discriminate between alternative explanations for the observed trends.

Acemoglu (2002b) also compares the US trends from the CPS with the LIS evidence to see whether the relative supply-and-demand framework with a common technology

35 Australia, Canada, Finland, Germany, Israel, Italy, Netherlands, Norway, Poland, Sweden, Taiwan and UK. 
trend for all countries provides a satisfactory explanation for the differential behavior of skill premia in the USA and Europe. He argues that it does not, and develops a model where labor market institutions creating wage compression also encourage more investment in technologies that increase the productivity of less-skilled workers and are therefore less skill-biased.

\section{The ISSP}

The ISSP is a voluntary grouping of national study teams, each of which collects repeated cross-sectional information using a common questionnaire. In addition to an annual theme question concerning social attitudes on topics such as political views or issues of work and family, the ISSP each year collects basic demographic and income information from respondents. The ISSP has grown from 4 countries in 1984 (Australia, Germany, UK and USA) to the current 38 countries.

Unfortunately, the size of the ISSP samples tends to be quite small. Further, most countries provide earnings only in bracketed amounts that differ across countries and over time. As a result, the ISSP data may not replicate the patterns from other data sets that provide nonbracketed amounts from larger samples. In particular, "the ISSP data for the United States does not show the upward trend in inequality found in the CPS and other data sets" [Gottschalk and Joyce (1998)].

Trostel, Walker and Wooley (2002) use the ISSP data for the period 1985-1995 to estimate the Mincerian return to education separately for 28 countries, both developed and developing. With log hourly wages of employees aged 21-59 as the outcome variable, they obtain pooled estimates of the rate of return to schooling just under $5 \%$ for men and a little under $6 \%$ for women, but find the cross-country variation in the estimates "quite striking" and "difficult to explain". Returns are generally higher outside Continental Europe, "but this seems to be the only clear pattern". There is "tenous evidence that the rate of return declines with average educational attainment [...], per capita income and [...] relative spending on education". Consistently with progressivity of labor income taxation, there is "somewhat stronger evidence that the estimated rate of return is higher when wages are measured before taxes than after taxes". Looking at time trends over the 1985-1995 period, they find no evidence for a worldwide rising rate of return to education. For women, they actually find some evidence of a declining rate.

\section{The ECHP}

The ECHP is a standardized multi-purpose annual longitudinal survey carried out at the level of the European Union (EU) between 1994 and 2001 (in 12 countries from 1994 and all 15 countries from 1996). The survey was centrally designed and coordinated by the Statistical Office of the European Communities (Eurostat), and covered demographics, labor force behavior, income, health, education and training, housing, migration, etc. It was aimed at being both cross-sectionally and longitudinally representative, with changes in the population over time reflected by the continuous evolution of the sample 
- through births to sample households and the formation of new households from the split off of existing ones. ${ }^{36}$

In this section, I present estimates of model (2) from the first seven waves of the ECHP $^{37}$ and from the US March CPS for the period 1994-2000. I consider average weekly earnings of full-time employees, defined as the ratio between the sum of wage and salary earnings in the calendar year prior to the survey divided by the number of weeks worked. For both the CPS and the ECHP, wages and salaries consist of all forms of cash wage and salary income (including employer bonuses, 13th month bonus, etc.) and, with the exception of Finland, France and the USA, are post-tax. Weeks worked are directly reported in the CPS, whereas for the ECHP they are obtained multiplying the number of months worked by 4 . Unfortunately, the monthly calendar of main activity is not available for the Netherlands and Sweden, which are therefore excluded from the sample.

For both the CPS and the ECHP, educational attainments are measured by the highest level of education completed. The classification adopted by the ECHP is very coarse, however, for it only distinguishes three levels: the first level ("less than second stage of secondary education") corresponds to ISCED levels 1 and 2, the second level ("second stage of secondary education") corresponds to ISCED levels 3 and 4, and the last one ("recognized third level education") corresponds to ISCED levels 5 and 6 . The fact that the ECHP does not separate primary and lower secondary education is a serious problem for Southern European countries (Greece, Italy, Portugal and Spain), where a large fraction of people of older age at most have completed primary education.

I estimate model (2) by OLS for each country, separately for men and women, with potential experience replaced by age. To capture trends in the structure of wages, the educational dummies and the quadratic age term are fully interacted with a linear time trend. The parameters presented in Table 7 correspond to the level of the educational premia in 1993 and their average annual variation between 1993 and 1999. Crosscountry differences in the initial level of the educational premia are not easy to interpret because they reflect differences in the average annual return to education as well as differences in the number of years that each educational level requires beyond the first (less than second stage of secondary education) and the earnings concept used (pre- or post-tax). There is clear evidence of an increase of educational premia for the USA, whereas the evidence for the European countries is mixed. For example, the college premium is increasing for both men and women in Greece, only for men in Germany and Luxembourg, and only for women in Belgium and Denmark, but is decreasing for men in Ireland and Italy.

\footnotetext{
36 See Peracchi (2002) for more details.

37 For Germany, Luxembourg and the UK, the public-use version of the ECHP contains two data sets for the first three waves, one from the original ECHP and the other from pre-existing national panels, namely the German Socioeconomic Panel (SOEP), the Luxembourg's Social Economic Panel, and the British Household Panel Survey (BHPS), whereas for the later waves it only contains the comparable data derived from the national panels. For these three countries, I disregard the original ECHP data and only work with the data from the national panels.
} 
Table 7

Educational wage premia in the countries of the European Union and the USA. Initial level in 1993 and trend in 1993-1999

\begin{tabular}{|c|c|c|c|c|}
\hline & \multicolumn{2}{|c|}{ College premium } & \multicolumn{2}{|c|}{ High-school premium } \\
\hline & Level & Trend & Level & Trend \\
\hline \multicolumn{5}{|l|}{ Men } \\
\hline Austria & $.437^{* *}$ & .008 & $.197^{* *}$ & -.017 \\
\hline Belgium & $.280^{* *}$ & .010 & .032 & .008 \\
\hline Denmark & $.251^{* *}$ & .002 & $.108^{* *}$ & -.004 \\
\hline Finland & $.481^{* *}$ & -.020 & $.177^{*}$ & -.038 \\
\hline France & $.618^{*}$ & .009 & $.116^{* *}$ & .014 \\
\hline Germany & $.234^{* *}$ & $.022^{* *}$ & .032 & -.003 \\
\hline Greece & $.370^{* *}$ & $.020^{* *}$ & $.200 * *$ & .011 \\
\hline Ireland & $.502^{* *}$ & $-.020^{*}$ & $.249^{* *}$ & $-.015^{*}$ \\
\hline Italy & $.457^{* *}$ & $-.023^{* *}$ & $179^{* *}$ & -.000 \\
\hline Luxembourg & $.616^{* *}$ & $.021^{*}$ & $.277^{* *}$ & .004 \\
\hline Portugal & $.995^{* *}$ & -.003 & $.381^{* *}$ & $.029^{* *}$ \\
\hline Spain & $.507^{* *}$ & .004 & $.267^{* *}$ & .007 \\
\hline UK & $.273^{* *}$ & .002 & $.109^{* *}$ & .016 \\
\hline USA & $.787^{* *}$ & $.012^{* *}$ & $.400^{* *}$ & .003 \\
\hline \multicolumn{5}{|l|}{ Women } \\
\hline Austria & $.577^{* *}$ & -.036 & $.265^{* *}$ & -.010 \\
\hline Belgium & $.271^{* *}$ & $.022^{*}$ & $.106^{* *}$ & .014 \\
\hline Denmark & $.193^{* *}$ & $.015^{*}$ & $.110^{* *}$ & .007 \\
\hline Finland & $.372^{* *}$ & -.005 & .143 & -.019 \\
\hline France & $.521^{* *}$ & -.008 & $.143^{* *}$ & -.002 \\
\hline Germany & $.207^{* *}$ & .018 & .022 & .011 \\
\hline Greece & $.399^{* *}$ & $.037^{* *}$ & $.279^{* *}$ & .003 \\
\hline Ireland & $.644^{* *}$ & .003 & $.282^{* *}$ & -.002 \\
\hline Italy & $.424^{* *}$ & .004 & $.322^{* *}$ & -.001 \\
\hline Luxembourg & $.714^{* *}$ & -.007 & $.353^{* *}$ & .005 \\
\hline Portugal & $1.015^{* *}$ & .010 & $.540^{* *}$ & .005 \\
\hline Spain & $.649^{* *}$ & -.006 & $.357^{* *}$ & -.008 \\
\hline UK & $.355^{* *}$ & -.003 & $.195^{* *}$ & .004 \\
\hline USA & $.859^{* *}$ & $.010^{*}$ & $.391^{* *}$ & $.012^{* *}$ \\
\hline
\end{tabular}

** denotes an observed significance level below $1 \%$,

*denotes an observed significance level between 1 and $5 \%$.

\section{Education and the distribution of personal earnings}

I now turn to the implication of the differences in the educational composition of the workforce and the evolution of educational wage premia for the differences in the distribution of labor earnings across countries and over time. How much of the variability of 
earnings can be accounted for by the differences in wage premia? How much do changes in wage premia across countries and over time help explain changes in the distribution of earnings? ${ }^{38}$

\subsection{Methodological aspects}

The literature offers various ways of formally looking at the relationship between educational premia, relative supply of workers by schooling levels, and the distribution of personal earnings. One exploits the decomposition of the total variance of log earnings into three components, reflecting respectively the variation between schooling levels, the variation between other characteristics within each schooling level, and the residual variation within schooling levels and other characteristics. Another tries instead to decompose changes in the conditional quantiles of log earnings. More recently, some attention has also been devoted to the decomposition of earnings inequality into permanent and transitory components. ${ }^{39}$

\section{Variance decomposition}

Let $\mu$ and $\sigma^{2}$ respectively denote the unconditional mean and variance of log earnings $Y$, let $\mu(s)$ and $\sigma^{2}(s)$ respectively denote the conditional mean and the conditional variance of log earnings among workers with schooling level $S=s$, and let $\mu(s, x)$ and $\sigma^{2}(s, x)$ respectively denote the conditional mean and the conditional variance of $\log$ earnings among workers with schooling level $S=s$ and other observable characteristics $X=x$ (age, potential labor market experience, etc.).

The unconditional mean of log earnings may be written

$$
\mu=\sum_{s} \mu(s) p(s)=\sum_{s}\left[\sum_{x} \mu(s, x) p(x \mid s)\right] p(s)=\sum_{s, x} \mu(s, x) p(s, x),
$$

where $p(s)$ denotes the relative frequency of workers with schooling level $s, p(x \mid s)$ denotes the relative frequency of workers with characteristics $x$ among those with schooling level $s$, and $p(s, x)=p(x \mid s) p(s)$ denotes the relative frequency of workers with schooling level $s$ and other observable characteristics $x$. This relationship can be used to formally decompose the difference $\mu_{j t}-\mu_{k t}$ between country $j$ and country $k$ at a given time $t$, or the difference $\mu_{j t}-\mu_{j r}$ between time $r$ and time $t$ for the same country $j$. For example,

$$
\begin{aligned}
\mu_{j t}-\mu_{j r}= & \sum_{s, x}\left[\mu_{j t}(s, x)-\mu_{j r}(s, x)\right] p_{j t}(s, x) \\
& +\sum_{s, x} \mu_{j r}(s, x)\left[p_{j t}(s, x)-p_{j r}(s, x)\right] .
\end{aligned}
$$

\footnotetext{
38 A much more complicated problem, not addressed here, is how changes in the distribution of earnings contribute to changes in the distribution of total household income.

39 In what follows, I ignore the complications arising from the fact that the relevant population concepts are typically unknown and must be estimated using sample counterparts.
} 
Clearly, $\mu_{j t}-\mu_{j r}=\sum_{s, x}\left[\mu_{j t}(s, x)-\mu_{j r}(s, x)\right] p_{j t}(s, x)$ if the distribution of workers by schooling level and other observable characteristics does not change over time, and $\mu_{j t}-\mu_{j r}=\sum_{s, x} \mu_{j r}(s, x)\left[p_{j t}(s, x)-p_{j r}(s, x)\right]$ if instead the conditional mean of log earnings does not change over time.

Similarly, the unconditional variance of log earnings may be decomposed as follows

$$
\begin{aligned}
\sigma^{2}= & \sum_{s}[\mu(s)-\mu]^{2} p(s)+\sum_{s} \sigma^{2}(s) p(s) \\
= & \sum_{s}[\mu(s)-\mu]^{2} p(s)+\sum_{s, x}[\mu(s, x)-\mu(s)]^{2} p(s, x) \\
& +\sum_{s, x} \sigma^{2}(s, x) p(s, x)
\end{aligned}
$$

This may be written

$$
\sigma^{2}=\sum_{s}[A(s)+B(s)+W(s)] p(s),
$$

where the first term

$$
\sum_{s} A(s) p(s)=\sum_{s}[\mu(s)-\mu]^{2} p(s)
$$

measures the contribution of the variation of mean log earnings across schooling levels, the second term

$$
\sum_{s} B(s) p(s)=\sum_{s, x}[\mu(s, x)-\mu(s)]^{2} p(x \mid s) p(s)
$$

measures the contribution of the variation of mean log earnings across workers with the same schooling level but different values of the other observable characteristics, and the third term

$$
\sum_{s} W(s) p(s)=\sum_{s, x} \sigma^{2}(s, x) p(x \mid s) p(s)
$$

measures the contribution of the residual variation of log earnings within groups of workers with the same observable characteristics (within-group inequality). If $\mu(s, x)=$ $\alpha_{s}+g(x)$ and $\sigma^{2}(s, x)=\omega^{2}$ (homoskedastic partially linear model), then

$$
\begin{aligned}
& \sum_{s} A(s) p(s)=\sum_{s}\left(\alpha_{s}-\bar{\alpha}+\bar{g}_{s}-\bar{g}\right)^{2} p(s), \\
& \sum_{s} B(s) p(s)=\sum_{s, x}\left[g(x)-\bar{g}_{s}\right]^{2} p(x \mid s) p(s), \\
& \sum_{s} W(s) p(s)=\omega^{2},
\end{aligned}
$$

where $\bar{\alpha}=\sum_{s} \alpha_{s} p(s), \bar{g}_{s}=\sum_{x} g(x) p(x \mid s)$, and $\bar{g}=\sum_{s} \bar{g}_{s} p(s)$. 
The ratio

$$
\frac{\sum_{s} W(s) p(s)}{\sigma^{2}}=1-\frac{\sum_{s}[A(s)+B(s)] p(s)}{\sum_{s}[A(s)+B(s)+W(s)] p(s)}
$$

measures the relative contribution of the within-group variation to the total variance of $\log$ earnings. This ratio is equal to one minus the population $R^{2}$ in a regression of $\log$ earnings on schooling and other observable characteristics. Hence, the importance of the within-group inequality depends crucially on what worker characteristics are considered beside schooling, and may be reduced by controlling for more worker characteristics or by specifying a more flexible model for the conditional mean $\mu(s, x)$.

More compactly, (8) may be written

$$
\sigma^{2}=\sum_{s} C(s) p(s)
$$

where $C(s)=A(s)+B(s)+W(s)$. This gives a straightforward way of formally decomposing the difference $\sigma_{j t}^{2}-\sigma_{k t}^{2}$ between country $j$ and country $k$ at a given time $t$, or the difference $\sigma_{j t}^{2}-\sigma_{j r}^{2}$ between time $r$ and time $t$ for the same country $j .{ }^{40}$ For example

$$
\sigma_{j t}^{2}-\sigma_{j r}^{2}=\sum_{s}\left[C_{j t}(s)-C_{j r}(s)\right] p_{j t}(s)+\sum_{s} C_{j r}(s)\left[p_{j t}(s)-p_{j r}(s)\right] .
$$

Clearly $\sigma_{j t}^{2}-\sigma_{j r}^{2}=\sum_{s}\left[C_{j t}(s)-C_{j r}(s)\right] p_{j t}(s)$ if the marginal distribution of workers by schooling level does not change over time, and $\sigma_{j t}^{2}-\sigma_{j r}^{2}=\sum_{s} C_{j r}(s)\left[p_{j t}(s)-\right.$ $\left.p_{j r}(s)\right]$ if only the marginal distribution of workers by schooling level changes over time.

\section{Other approaches}

In practice, the variance decomposition (8) has three main drawbacks. First, it focuses only on the first two moments of the conditional distribution of earnings. Second, the variance of log earnings is mathematically convenient but need not be a good measure of dispersion, unless earnings are approximately log normal. Third, standard estimates of $\mu_{j t}(s, x)$ and $\sigma_{j t}^{2}(s, x)$ are very sensitive to the presence of outliers.

To avoid reliance on the variance as a measure of earnings dispersion, and to increase the robustness of the decomposition into between and within (residual) variation, Juhn, Murphy and Pierce (1993) assume the following linear model for log earnings $Y_{i j t}$ of individual $i$ in country $j$ at time $t$

$$
Y_{i j t}=\gamma_{j t} Z_{i j t}+U_{i j t}
$$

40 See, for example, Katz and Autor (1999) and Welch (1999). 
where $Z_{i j t}$ is a vector of observable worker characteristics (including education), $\gamma_{j t}$ is a (row) vector of prices of the observable skills, and $U_{i j t}$ is an unobservable determinant of log earnings (or "residual") whose conditional distribution given $Z_{i j t}$ is represented by a continuous and invertible distribution function $F_{j t}$. Dropping for simplicity the subscript $j$ and letting $\theta_{i t}=F_{t}\left(U_{i t}\right)$ denote the conditional percentile position of individual $i$ given $Z_{i t}$, one can write

$$
Y_{i t}=\gamma_{t} Z_{i t}+F_{t}^{-1}\left(\theta_{i t}\right)
$$

where $F_{t}^{-1}$ denotes the conditional quantile function of the residual. Notice that both the percentile position $\theta_{i t}$ and the quantile function $F_{t}^{-1}$ may change over time.

If $\gamma_{r}$ and $F_{r}^{-1}$ denote skill prices and the quantile function of the residual for some base period $r,{ }^{41}$ then

$$
Y_{i t}=\gamma_{r} Z_{i t}+\left(\gamma_{t}-\gamma_{r}\right) Z_{i t}+F_{r}^{-1}\left(\theta_{i t}\right)+\left[F_{t}^{-1}\left(\theta_{i t}\right)-F_{r}^{-1}\left(\theta_{i t}\right)\right] .
$$

If skill prices and the distribution function of the regression error did not change between time $r$ and time $t$, then individual earnings would be given by

$$
Y_{i t}^{(1)}=\gamma_{r} Z_{i t}+F_{r}^{-1}\left(\theta_{i t}\right) \text {. }
$$

Thus, Juhn, Murphy and Pierce (1993) attribute changes through time in the distribution of $Y_{i t}^{(1)}$ to changes in observable skills. On the other hand, if only the distribution function of the unobservable component did not change over time, then individual earnings would be given by

$$
Y_{i t}^{(2)}=Y_{i t}^{(1)}+\left(\gamma_{t}-\gamma_{r}\right) Z_{i t}
$$

Thus, they attribute the additional changes through time in the distribution of $Y_{i t}^{(2)}$ to changes in skill prices. Finally, because

$$
Y_{i t}=Y_{i t}^{(2)}+\left[F_{t}^{-1}\left(\theta_{i t}\right)-F_{r}^{-1}\left(\theta_{i t}\right)\right],
$$

they attribute the residual changes through time in the distribution of $Y_{i t}$ to changes in the distribution of the unobservables.

Both (8) and (9) only require repeated cross-sectional data to be estimated. This largely explains their popularity. With the increasing availability of long panel data, however, it becomes possible to decompose changes in annual earnings inequality into a persistent component (lifetime earnings becoming more or less equal) associated with the returns to education and other permanent worker characteristics, and a transitory component (lifetime earnings becoming more or less unstable). Unfortunately, the results of this kind of decomposition appear to be very sensitive to the choice of model for earnings dynamics. ${ }^{42}$ Further, unless sample attrition is ignorable, using long panel data raises delicate problems of self-selection into the sample.

41 The choice of the base period matters. For example, Goldin and Margo (1992) find that "the choice of base year greatly affects the importance of changes in the distribution of residuals relative to changes in both prices and quantities".

42 See Haider (2001). 


\subsection{Empirical evidence}

Unlike the evidence on educational premia, that on the distribution of earnings is much more scattered and unsystematic. The vast majority of the available evidence is for the USA. The stylized facts for the USA, on which there is a broad consensus, may be summarized as follows. First, inequality has increased both between groups, and within group. Second, the increase in between-group inequality is entirely due to the increase in age and schooling differentials, whereas gender and race differentials have instead declined. Third, the increase in between-group inequality accounts for a smaller share of the growth in inequality relative to residual inequality, that is, increased dispersion within groups. Fourth, lifetime earnings inequality has also increased [Haider (2001)].

As pointed out by Katz and Autor (1999), however, "trends in overall and residual inequality ... are less consistent across data sources and are more sensitive to the choice of the lower cut-off (i.e., handling of outliers), top-coding, and choice of sample (fulltime, all), earnings concept (weekly, hourly) and weights (bodies, weeks, labor hours supplied)". They conclude that "although all data sources point to a growth of residual inequality starting in the 1970 s, the relative magnitude, precise timing, and samplespecificity of this trend are elusive. These vagaries are unfortunate because shifts in the residual earnings distribution are less well understood than 'between group' inequality and, moreover, account for the preponderance of recent inequality growth by most estimates. To make further progress in understanding these trends, researchers should carefully explore the robustness of their conclusions to choice of data source, sub-sample and methodology".

In the remainder of this section I briefly review some of the available evidence for other countries, mainly developed economies. Most of the studies considered adopt decompositions similar to (8) or (9). In fact, no country except the USA and Canada seem to have the long panel data needed in order to estimate the decomposition of the variance of log earnings into a permanent and a transitory component.

\section{Single-country studies}

Table 8 reviews some recent single-country studies, focusing on developed countries because of the very limited evidence available for transition economies and developing countries. This review is only meant to provide an illustration of the heterogeneity in the data and the findings of these studies.

\section{Multi-country studies}

Katz, Loveman and Blanchflower (1995) analyze the trends in the wage structure and the overall wage inequality in France, Germany, UK and the USA during the 1970s and the 1980s. Although their data and earnings measures are only roughly comparable, they find that "all four countries share a pattern of rising wage inequality among both men and women in the 1980s, but the magnitude of the increases differ substantially". 
Table 8

Earnings inequality. Single country studies

\begin{tabular}{|c|c|c|c|c|}
\hline Country & Reference & Data set & Years & Main findings \\
\hline \multirow[t]{2}{*}{ Canada } & $\begin{array}{l}\text { Burbidge, Magee and } \\
\text { Robb (1997) }\end{array}$ & $\mathrm{SCF}$ & $1971-93$ & $\begin{array}{l}\text { There was an increase in over- } \\
\text { all wage dispersion between } \\
1975 \text { and } 1985 \text {, more pro- } \\
\text { nounced for female workers, } \\
\text { and a leveling off after } 1985 \text {. } \\
\text { Wage dispersion appears to } \\
\text { have risen for all educational } \\
\text { and experience groups, except } \\
\text { older male and female univer- } \\
\text { sity graduates. For all educa- } \\
\text { tional groups, the most sig- } \\
\text { nificant increase in wage dis- } \\
\text { persion occurred for younger } \\
\text { workers. }\end{array}$ \\
\hline & $\begin{array}{l}\text { Baker and Solon } \\
(2003)\end{array}$ & $\begin{array}{l}\text { Random sample } \\
\text { of income tax } \\
\text { forms issued by } \\
\text { employers (T-4 } \\
\text { Supplementary } \\
\text { Tax File) }\end{array}$ & 1976-92 & $\begin{array}{l}\text { They decompose the growth of } \\
\text { earnings inequality in Canada } \\
\text { during the period into a per- } \\
\text { sistent (long-run) and a transi- } \\
\text { tory component. They find that } \\
\text { "the increase in the persistent } \\
\text { component may have played a } \\
\text { somewhat larger role". }\end{array}$ \\
\hline
\end{tabular}

Germany Fitzenberger et al. Random sample 1976-84 They find that the German (2001) of Social Security accounts wage structure was fairly stable during the period considered, although wage inequality within age-education groups increased slightly above the median. They interpret this evidence as the outcome of the institutional aspects of wage setting in Germany and the baby boom effect on cohort size.

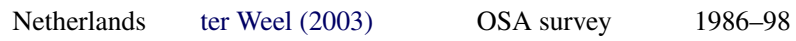

Using decomposition (9), he finds that wage inequality did not increase much during the period considered, that most of the changes in wage inequality are accounted for by changes in the educational level and experience composition of the labor force, and that residual wage inequality does not play an important role. 
Table 8

(Continued)

\begin{tabular}{llll}
\hline Country & Reference & Data set & Years \\
\hline Portugal & Cardoso (1998) & $\begin{array}{l}\text { Quadros de Pes- } \\
\text { soal }\end{array}$ & $1983-1992$
\end{tabular}

Main findings

Rising earnings inequality, especially after 1986, due to a substantial widening of the wage gap across schooling levels, with the returns to college education sharply increasing relative to the other schooling levels. "Forces operating within industries have contributed to switch the relative demand in favor of very qualified workers". At the same time, "the minimum wage legislation and collective bargaining ... contributed to compress the bottom part of the wage distribution in the early eighties, whereas wage drift led to rising dispersion at the top of the distribution".

UK

Gosling, Machin and FES, GHS

Meghir (2000)

1966-95 Using decomposition (9), they find that about a third of the increase in wage dispersion during the period is due to increases in educational premia, a third is due to a continuous decline in the growth rate of wages of successive cohorts entering the labor market, and the remaining third is within group, as successive cohorts enter the labor market with increased dispersion of wages. This increased dispersion may partly have to do with the increased heterogeneity of educational qualifications of people with the years of schooling.

The UK and the USA both display a sharp increase, while the increase in Japan is much more moderate. France experience declining inequality until 1984 and a moderate increase from 1984 to 1990 . Changes in education/occupation differentials appear to be the driving force. A unique feature of the UK and the USA, however, is the fact that 
wage inequality increased for both men and women with similar education and experience levels. They argue that "simple supply and demand measures go a reasonable distance towards explaining the differences and similarities between these countries in patterns of relative wage movements. ... Institutional differences across the countries translated the relative demand shifts against less educated workers into similar outcomes of sharply rising inequality in the United States and Britain in the 1980s but a very different outcome in France through the mid-1980s. . . Finally, the strength of the Japanese manufacturing sector may partially account for the much smaller magnitude of changes in skill differentials in Japan than in Britain and the United States".

Blau and Kahn (1996) compare the level of male earnings inequality in the USA and 9 other industrialized countries ${ }^{43}$ around the mid-1980s using the decomposition (9). In addition to ISSP data for Austria, Germany, Hungary, Norway, Switzerland, UK and USA, they employ a variety of other sources. ${ }^{44}$ After examining indices of relative supplies and demands of skills across countries, they observe that "low-skill workers should fare worse relative to middle-skill workers in other countries than they do in the United States". They conclude that "market forces [...] do not appear to be a viable explanation for international differences, further increasing our confidence that [labor market] institutions are important".

Gottschalk and Smeeding (1997) review the evidence from various studies that contrast the US experience during the 1980s with that of other developed countries. ${ }^{45}$ They summarize the available evidence on the levels of earnings inequality as follows:

1. "At any given time there are wide differences across modern countries in the level of earnings inequality for both men and women".

2. "Nations with centralized wage bargaining (e.g., Sweden, Germany) have greater equality than nations with less centralized bargaining (e.g., the United States and Canada)".

They summarize the trends in earnings inequality as follows: ${ }^{46}$

1. "Almost all industrial economies experienced some increase in wage inequality among prime aged males during the 1980s (Germany and Italy are the exceptions)".

2. "But large differences in trends also exist across countries, with earnings inequality increasing most in the United States and the United Kingdom and least in Nordic countries".

43 Australia, Austria, Germany, Hungary, Italy, Norway, Sweden, Switzerland, and the UK.

44 The other sources are the 1986 Income Distribution Survey for Australia, the 1987 Survey of Household Income and Wealth (SHIW) for Italy, the Class Structure and Class Consciousness (CSCC) data base for Norway (1982) and Sweden (1980), the 1984 Household Market and Nonmarket Activities Survey (HUS) for Sweden, and the 1984 Panel Study of Income Dynamics (PSID) for the USA.

45 Australia, Canada, Finland, France, Germany, Israel, Italy, Japan, Netherlands, Sweden, and the UK.

46 They also claim that "as a result of allowing market forces to influence wages, Russia, Hungary, and the former East Germany experienced considerably larger percentage changes in earnings inequality than the United States or the United Kingdom". 
3. "The increasing demand for more skilled workers, coupled with differences across countries in the growth in supply of skilled workers, explains a large part of differences in trends in returns to education and experience".

4. "Institutional constraints on wages also seem to matter. The rise in the relative unemployment rates of the least skilled in some, but not all, countries with centralized wage setting institutions suggests that constraints were at least partially responsible for limiting the rise in inequality".

Gottschalk (1997) classifies developed countries into four groups. One extreme is occupied by the UK and the USA, with very large increases in inequality, the other by Germany, "the only country that seems to have avoided any increase in inequality during the 1970s, 1980s or 1990s". A unique feature of the UK and the USA is the fact that they experienced large increases in the returns to both education and experience, as well as increases in inequality within groups. In between, he puts two groups of countries: those which experienced large but not extreme increases in inequality (Canada, Australia, Israel and New Zealand), and those which experienced small but positive changes in inequality (Finland, France, Italy, Japan, Netherlands and Sweden).

Gottschalk and Joyce (1998) use the LIS database to examine the contribution of changes in inequality between group and within group to changes in overall inequality of full-time male earnings. They find that the small overall increase in earnings inequality in many countries (and the small overall decline in some of them) actually reflects large but offsetting changes in returns to skill and changes in inequality within ageeducation cells, and conclude that "there is no clear relationship between the ranking of countries in changes in overall inequality and changes in within-group inequality".

Katz and Autor (1999) summarize the evidence provided by OECD (1996) on trends in wage inequality for men in 14 OECD countries ${ }^{47}$ between 1979 to 1994 . They find that "the United States and the United Kingdom experienced sharp increases in overall wage inequality, residual wage inequality and educational and occupational wage differentials of similar magnitude. ... The pattern of declining wage inequality apparent throughout the OECD (except the United States) in the 1970s ceased in the 1980s and 1990s in almost all nations (with Germany and Norway as possible exceptions). Canada, Australia, Japan, and Sweden had modest increases in wage inequality and educational/occupational differentials starting in the early 1980s. Wage differentials and inequality narrowed through the mid-1980s in Italy and France with some hint of expanding in France in the late 1980s and with a large increase in inequality in Italy in the 1990s". They argue that "these patterns are suggestive of an important role of differences and changes in labor market institutions and regulations. ... But differences in supply and demand factors may also play a role".

Devroye and Freeman (2001) look at the differences between Germany, Netherlands, Sweden and the USA in the sensitivity of the variance decomposition (8) to two alternative measures of skills, namely years of schooling and adult literacy scores in the OECD

47 Australia, Austria, Canada, Finland, France, Germany, Italy, Japan, Netherlands, New Zealand, Norway, Sweden, UK and USA. 
International Adult Literacy Survey. They reject the hypothesis that cross-country differences in the distribution of skills are the main determinants of cross-country differences in earnings inequality and instead conclude that "the explanation for cross-country differences in inequality lies, not in the distribution of skills, but in the mechanism by which different pay systems produce dispersion among otherwise similar people in similar situation".

\section{Europe versus the USA}

In this final section I compare the experience of the countries of the European Union (except Netherlands and Sweden) to that of the USA during the 1990s employing the variance decomposition (8). As before, I use the ECHP for the European Union and the March CPS for the USA. Since the earnings measure is average weekly earnings of full-time employees in the calendar year prior to the survey, the period considered goes from 1993 to 1999.

I begin by presenting some cross-sectional evidence obtained by pooling all the available waves of the data. Figure 9 shows the age-profile of the variance of log earnings for men and women. For all countries, except the UK, this variance tends to increase with age. Figure 10 shows the age-profile of the relative importance of the within-group

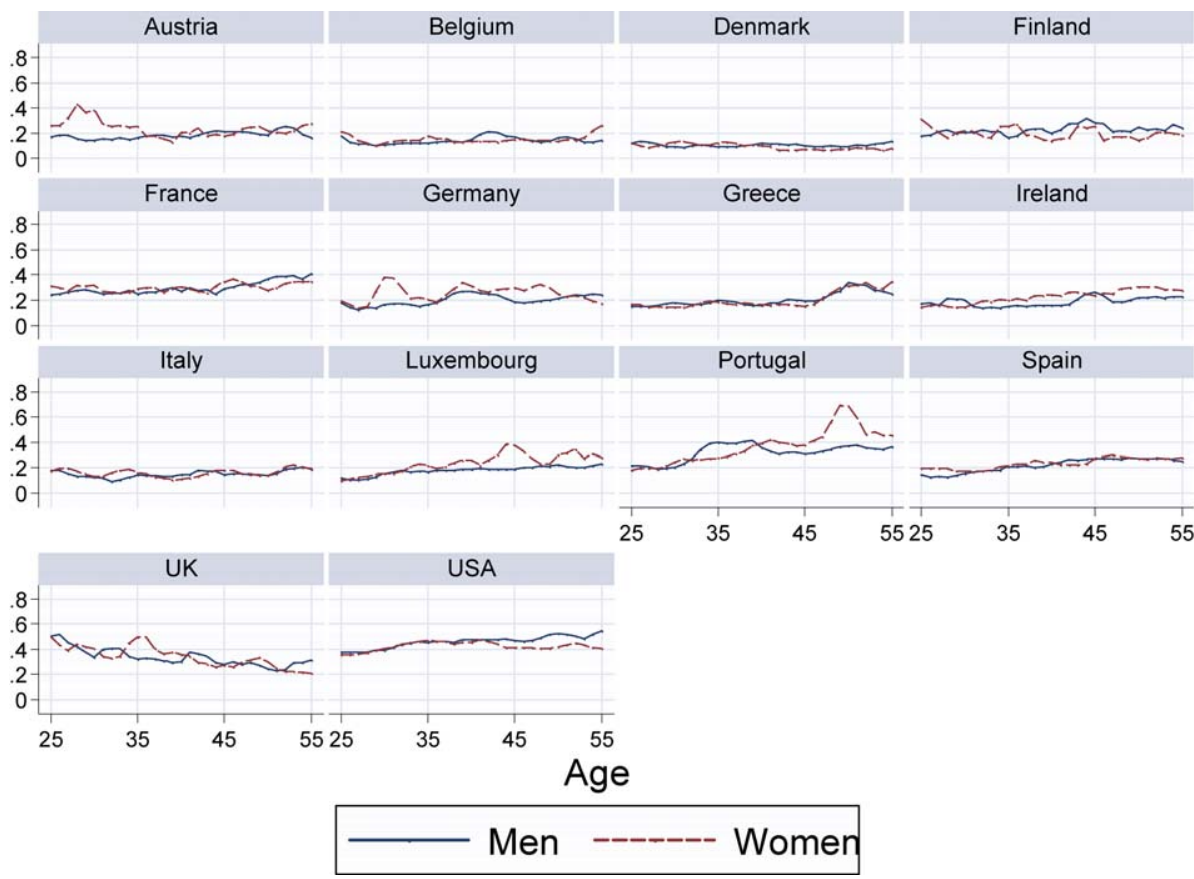

Figure 9. Variance of log earnings by age. 


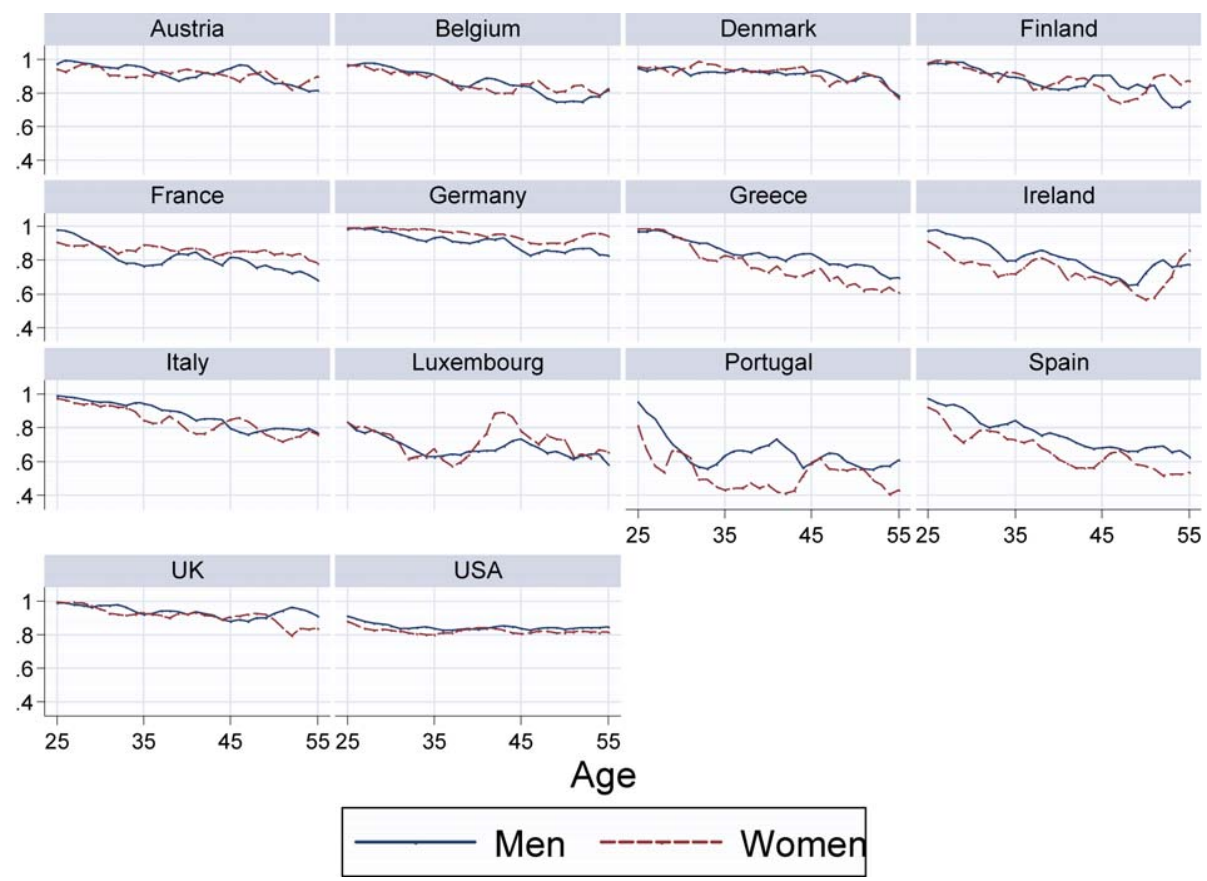

Figure 10. Contribution of the within-group component to the variance of log earnings by age.

component of the variance of log earnings. For both men and women and for all ages, more than half of the contribution to the variance of log earnings comes from the variation within educational levels. The importance of this component is generally higher for men than for women in Greece, Ireland, Portugal, Spain and the USA, whereas the opposite is true in France and Germany. What seems to differentiate the USA from the other countries is the fact that the contribution of the variation within educational levels is relatively stable at about 85 percent, irrespective of age. For most European countries, on the contrary, the importance of this component is very high at younger ages, but then declines with age. This decline appears to be quite rapid for Greece, Ireland, Portugal and Spain.

Figure 11 shows instead the time-profile of the total variance of log earnings separately for men and women. There is some evidence of an upward trend for Finland, Luxembourg and Portugal, but not for the other countries. Figures 12-14 show the time-profile of the relative contribution of the three components that enter the decomposition (8). Figure 12 shows the importance of the variance between schooling levels. The importance of this first component appears to be relatively stable in the UK and the USA, but rising in several European countries. Figure 13 shows the importance of the variance between ages within schooling levels. The importance of this second component appears to be stable in the UK and declining in the USA, but rising in most 

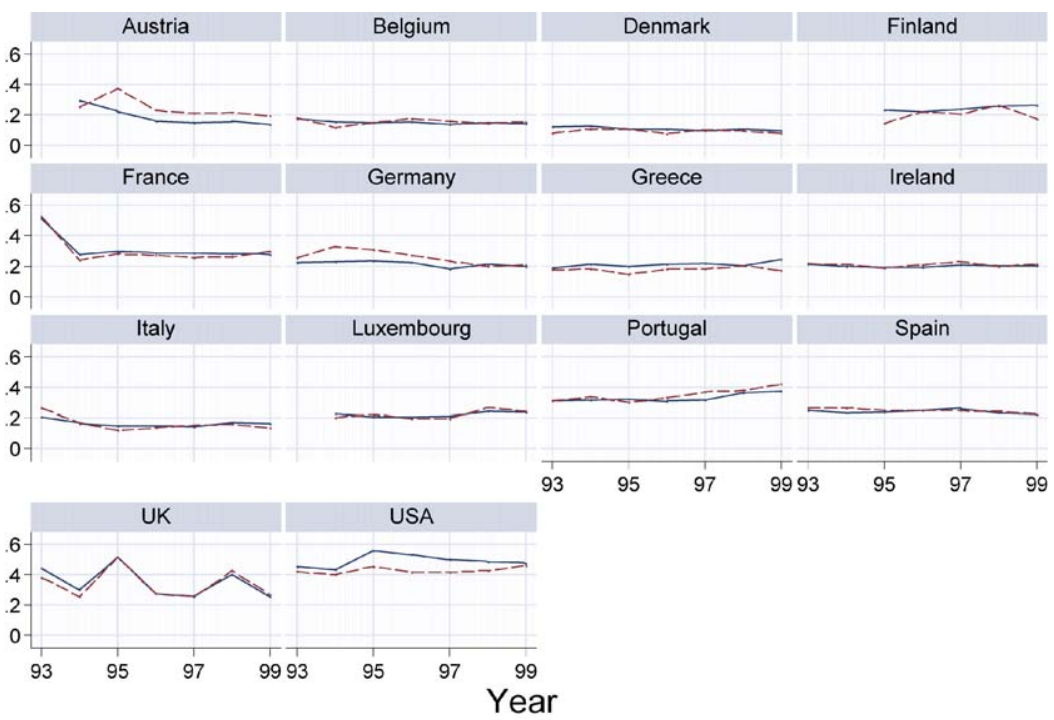

\section{Men}

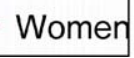

Figure 11. Total variance of log earnings.
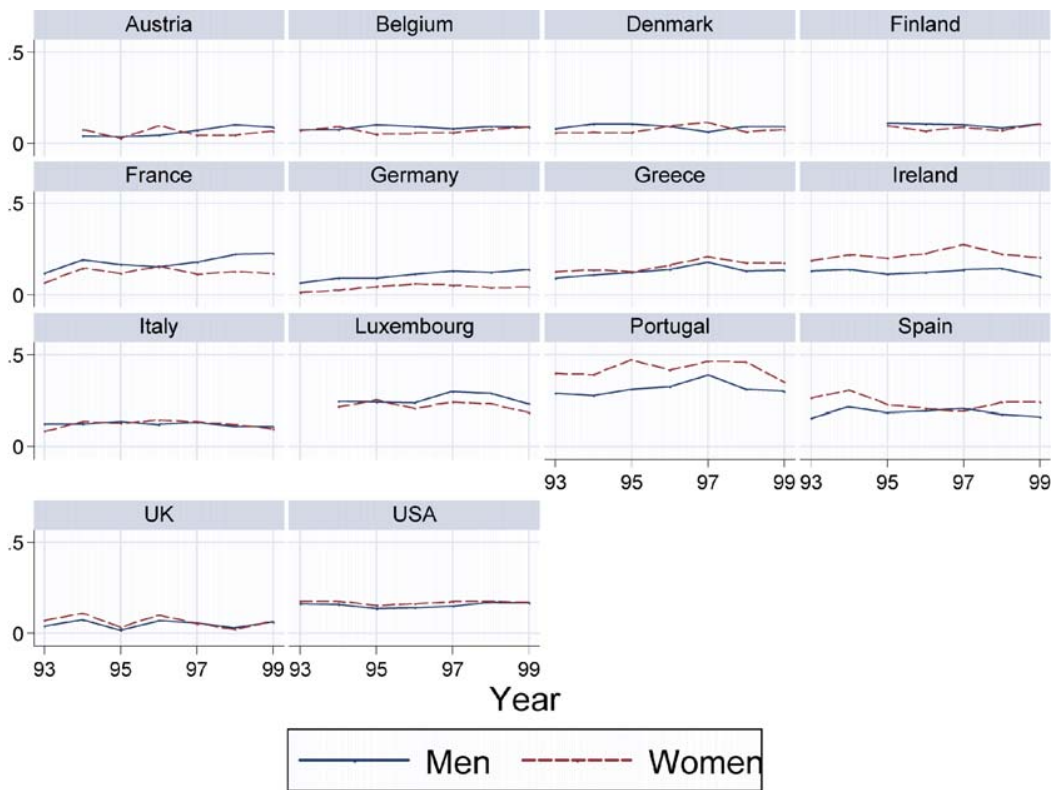

Figure 12. Relative contribution of the variance between schooling levels to the total variance of log earnings. 


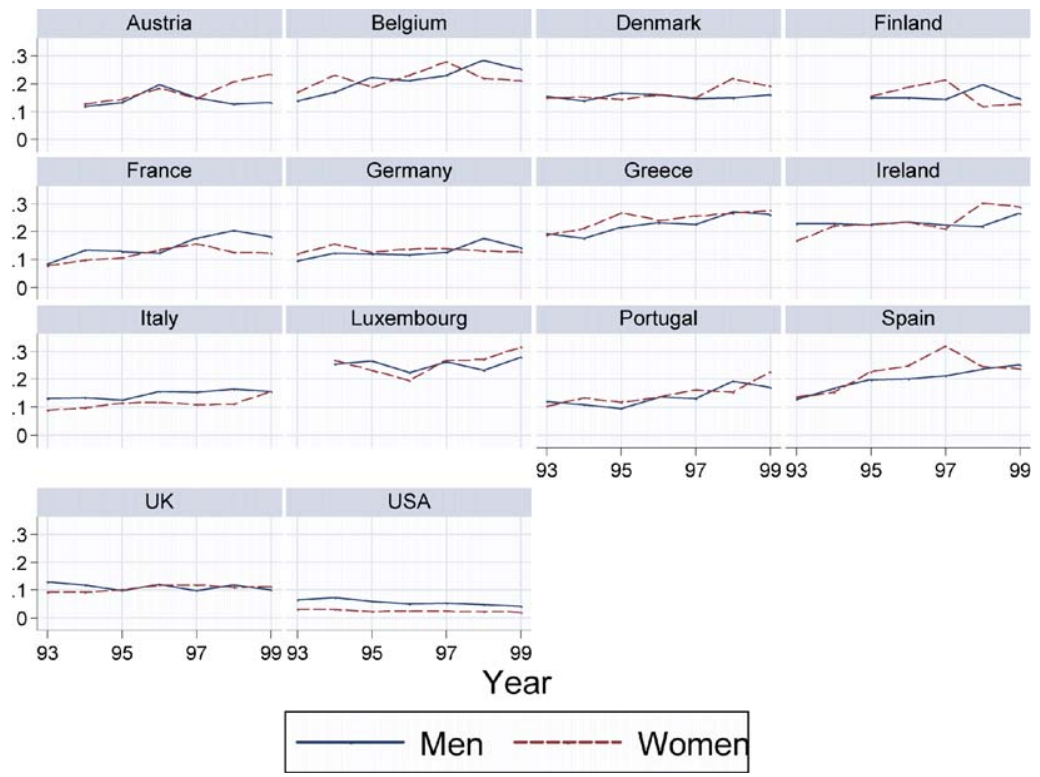

Figure 13. Relative contribution of the variance between ages within schooling levels to the total variance of log earnings.

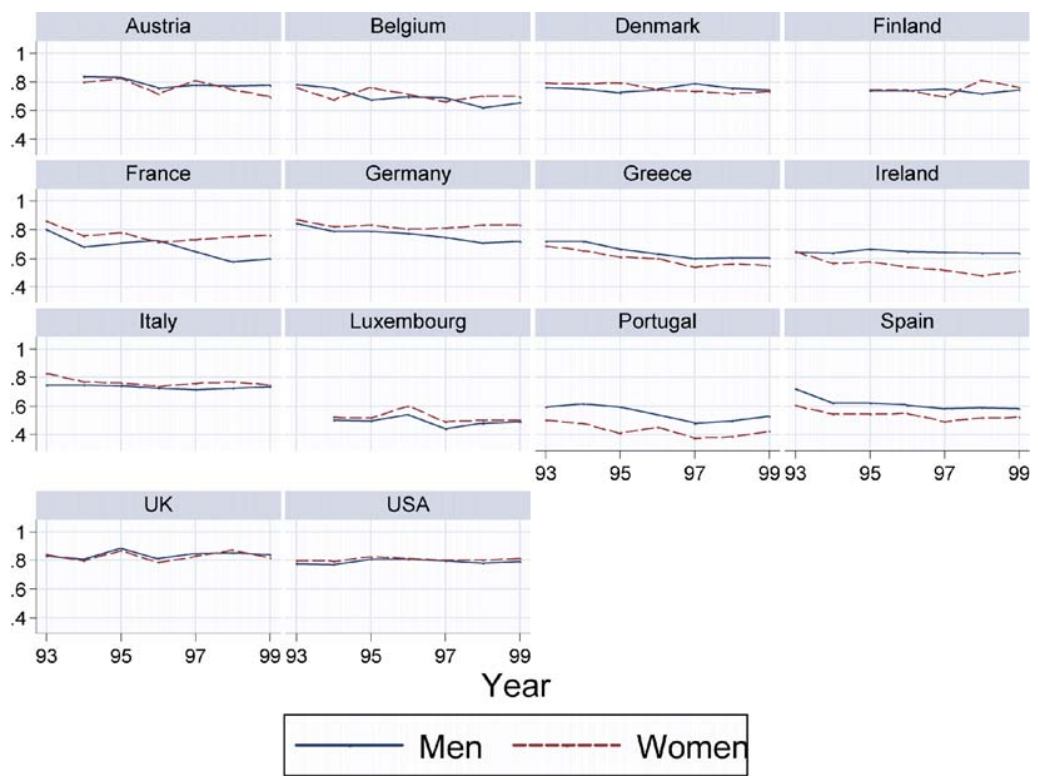

Figure 14. Relative contribution of the residual variance within age and schooling to the total variance of log earnings. 
other European countries. Finally, Figure 14 shows the importance of the residual variation within age and schooling. The importance of this third component appears to be increasing in the UK and the USA, but appears to be stable or even declining in most other European countries.

\section{Acknowledgements}

I would like to thank Antonio Ciccone, Don Deere, Ric Hanushek and especially Finis Welch for helpful comments.

\section{References}

Abadie, A. (1997). "Changes in Spanish labor income structure during the 1980s: A quantile regression approach". Investigaciones Economicas 21, 253-272.

Abraham, K.G., Houseman, S.N. (1995). "Earnings inequality in Germany". In: Freeman, R.B., Katz, L.F. (Eds.), Differences and Changes in Wage Structures. University of Chicago Press, Chicago.

Acemoglu, D. (2002a). "Technical change, inequality, and the labor market". Journal of Economic Literature $40,7-72$.

Acemoglu, D. (2002b). "Cross-country inequality trends". NBER Working Paper No. 8832.

Ashenfelter, O., Harmon, C., Oosterbeek, H. (1999). "A review of estimates of the schooling/earnings relationship, with tests for publication bias". Labour Economics 6, 453-470.

Asplund, R., Pereira, P.T. (1999). Returns to Human Capital in Europe. ETLA, The Research Institute of the Finnish Economy, Helsinki.

Atkinson, A.B., Brandolini, A. (2001). "Promise and pitfalls in the use of 'secondary' data sets: Income inequality in OECD countries as a case study". Journal of Economic Literature 39, 771-799.

Azuma, Y., Grossman, H.I. (2003). "Educational inequality”. Labour 17, 317-335.

Baker, M., Solon, G. (2003). "Earnings dynamics and inequality among Canadian men, 1976-1992: Evidence from longitudinal income tax records". Journal of Labor Economics 21, 289-321.

Bar-Or, Y., Burbidge, J., Magee, L., Robb, A.L. (1995). "The wage premium to a university education in Canada”. Journal of Labor Economics 13, 762-794.

Barrett, A., FitzGerald, J., Nolan, B. (2002). "Earnings inequality, returns to education and immigration in Ireland". Labour Economics 9, 665-680.

Barro, R., Lee, J.W. (1993). "International comparisons of educational attainment". Journal of Monetary Economics 32, 363-394.

Barro, R., Lee, J.W. (1996). "International measures of schooling years and schooling quality". American Economic Review Papers and Proceedings 86, 218-223.

Barro, R., Lee, J.W. (1997). "Schooling quality in a cross-section of countries". NBER Working Paper No. 6198.

Barro, R., Lee, J.W. (2000). "International data on educational attainment, updates and implications". NBER Working Paper No. 7911.

Bassanini, A., Scarpetta, S. (2002). "Does human capital matter for growth in OECD countries? A pooled mean-group analysis". Economics Letters 74, 399-405.

Beaudry, P., Green, D. (2000). "Cohort patterns in Canadian earnings: Assessing the role of skill premia in inequality trends". Canadian Journal of Economics 3, 907-936.

Beaudry, P., Green, D. (2003). "Wages and employment in the United States and Germany: What explains the difference?" American Economic Review 93, 573-602.

Becker, G.S. (1964). Human Capital. Columbia University Press, New York. 
Becker, G.S. (1967). Human Capital and the Personal Distribution of Income. University of Michigan Press, Ann Arbor.

Behrman, J.R., Birdsall, N., Székely, M. (2000). "Economic reform and wage differentials in Latin America". Inter-American Development Bank, Research Department Working Paper No. 435.

Benhabib, J., Spiegel, M.M. (1994). "The role of human capital in economic development: Evidence from aggregate cross-country data". Journal of Monetary Economics 34, 143-174.

Ben-Porath, Y. (1967). "The production of human capital and the life cycle of earnings". Journal of Political Economy 75, 352-365.

Berman, E., Bound, J., Machin, S. (1998). "Implications of skill-biased technological change: International evidence". Quarterly Journal of Economics 113, 1245-1279.

Betts, J.R. (1996). "What do students know about wages? Evidence from a survey of undergraduates". Journal of Human Resources 31, 27-56.

Bils, M., Klenow, P.J. (2000). "Does schooling cause growth?”. American Economic Review 90, 1160-1183.

Black, D., Sanders, S., Taylor, L. (2003). "Measurement of higher education in the Census and Current Population Survey". Journal of the American Statistical Association 98, 545-554.

Blau, F.D., Kahn, L.M. (1996). "International differences in male wage inequality: Institutions versus market forces". Journal of Political Economy 104, 791-836.

Blom, A., Holm-Nielsen, L., Verner, D. (2001). "Education, earnings and inequality in Brasil, 1982-98". World Bank Policy Research Working Paper No. 2686.

Bound, J., Jaeger, D., Baker, R. (1995). "Problems with instrumental variables estimation when the correlation between the instruments and exogenous explanatory variables is weak". Journal of the American Statistical Association 90, 443-450.

Bound, J., Johnson, G. (1992). "Changes in the structure of wages in the 1980's: An evaluation of alternative explanations". American Economic Review 82, 371-392.

Bourguignon, F., Morrisson, C. (2002). "Inequality among world citizens: 1820-1992". American Economic Review 92, 727-744.

Brunello, G., Comi, S., Lucifora, C. (2000). "The college wage gap in 10 European countries: Evidence from two cohorts". IZA Discussion Paper No. 228.

Brunello, G., Lucifora, C., Winter-Ebmer, R. (2001). "The wage expectations of European college students". Mimeo.

Burbidge, J.B., Magee, L., Robb, A.L. (1997). "Canadian wage inequality over the last two decades". Empirical Economics 22, 181-203.

Burbidge, J.B., Magee, L., Robb, A.L. (2001). "The education premium in Canada and the USA". QSEP Research Paper No. 364, McMaster University, Hamilton, Ontario.

Card, D. (2001). "Estimating the returns to schooling: Progress on some persistent econometric problems". Econometrica 69, 1127-1160.

Card, D., Lemieux, T. (2000). "Dropout and enrollment trends in the post-war period: What went wrong in the 1970s?". NBER Working Paper No. 7658.

Card, D., Lemieux, T. (2001). "Can falling supply explain the rising return to college for younger men? A cohort-based analysis". Quarterly Journal of Economics 116, 705-746.

Card, D., DiNardo, J.E. (2002). "Skill-biased technological change and rising wage inequality: Some problems and puzzles". Journal of Labor Economics 20, 733-783.

Cárdenas, M., Bernal, R. (1999). "Wage inequality and structural reforms: Evidence from Colombia”. Mimeo.

Cardoso, A. (1998). "Earnings inequality in Portugal: High and rising?". The Review of Income and Wealth 3 , 325-343.

Casavola, P., Gavosto, A., Sestito, P. (1996). "Technical progress and wage dispersion in Italy: Evidence from firms' data". Annales d'Économie et de Statistique 41-42, 387-412.

Cohen, D., Soto, M. (2002). "Why are some countries poor? Another look at the evidence and a message of hope". OECD Development Centre, Technical Paper No. 197.

Cragg, M.I., Epelbaum, M. (1996). "Why has wage dispersion grown in Mexico? Is the incidence of reforms or the growing demand for skills?". Journal of Development Economics 51, 99-116. 
Davis, S.J. (1992). "Cross-country patterns of change in relative wages”. NBER Working Paper No. 4085.

de la Fuente, A., Doménech, R. (2000). "Human capital in growth regression: How much difference does quality data make". CEPR Discussion Paper No. 2466.

de la Fuente, A., Doménech, R. (2001). "Educational attainment in the OECD, 1960-1995".

de la Fuente, A., Ciccone, A. (2003). Human Capital in a Global and Knowledge-Based Economy. Final Report. Office for Official Publications of the European Communities, Luxembourg.

Devroye, D., Freeman, R. (2001). "Does inequality in skills explain inequality of earnings across advanced countries". NBER Working Paper No. 8140.

Dominitz, J., Manski, C.F. (1996). "Eliciting student expectations of the returns to schooling". Journal of Human Resources 31, 1-26.

Dunne, M. (2003). "Education in Europe. Key statistics 2000/01". Statistics in Focus. Theme 3 (Population and Social Conditions). 13/2003. Eurostat, Luxembourg.

Duraisamy, P. (2002). "Changes in returns to education in India, 1983-94: By gender, age-cohort and location". Economics of Education Review 21, 609-622.

Duryea, S., Jaramillo, O., Pagés, C. (2002). "Latin American labor markets in the 1990s: Deciphering the decade". Mimeo, Research Department, Inter-American Development Bank.

Edin, P., Holmlund, B. (1995). "The Swedish wage structure: The rise and fall of solidarity wage policy?". In: Freeman, R.B., Katz, L.F. (Eds.), Differences and Changes in Wage Structures. University of Chicago Press, Chicago.

Erickson, C.L., Ichino, A. (1995). "Wage differentials in Italy: Market forces, institutions and inflation". In: Freeman, R.B., Katz, L.F. (Eds.), Differences and Changes in Wage Structures. University of Chicago Press, Chicago.

Ferreira, S.G. (2002). "The evolution of the college-high school wage differential for males in Brasil: Does an increasing supply of college-educated labor explain it". Department of Economics, University of Wisconsin-Madison.

Fersterer, J., Winter-Ebmer, R. (2003). “Are Austrian returns falling over time?” Labour Economics 10, 7389.

Filer, R.K., Jurajda, S., Plánovský, J. (1999). "Education and wages in the Czech and Slovak Republics during transition". Labour Economics 6, 581-593.

Fitzenberger, B., Hujer, R., MaCurdy, T.E., Schnabel, R. (2001). "Testing for uniform wage trends in WestGermany: A cohort analysis using quantile regression for censored data". In: Fitzenberger, B., Koenker, R., Machado, J.A.F. (Eds.), Economic Applications of Quantile Regression. Physica Verlag, Heidelberg.

Flanagan, R.J. (1998). "Were communists good human capitalists? The case of the Czech Republic". Labour Economics 5, 295-312.

Foster, A.D., Rosenzweig, M.R. (1996). "Technical change and human-capital returns and investment: Evidence from the green revolution". American Economic Review 86, 931-953.

Freeman, R.B. (1975a). "Supply and salary adjustments to the changing science manpower market: Physics, 1948-1973”. American Economic Review 65, 27-39.

Freeman, R.B. (1975b). "Legal cobwebs: A recursive model of the market for new lawyers". Review of Economics and Statistics 57, 171-179.

Freeman, R.B. (1986). "Demand for education”. In: Ashenfelter, O., Layard, R. (Eds.), Handbook of Labor Economics, vol. 1. North-Holland, Amsterdam.

Freeman, R.B., Katz, L.F. (1995). Differences and Changes in Wage Structures. Chicago University Press, Chicago.

Freeman, R.B., Schettkat, R. (2000a). "The role of wage and skill differences in US-German employment differences". NBER Working Paper No. 7474.

Freeman, R.B., Schettkat, R. (2000b). "Skill compression, wage differentials and employment: Germany versus the US". NBER Working Paper No. 7610.

Funkhouser, E. (1998). "Changes in the returns to education in Costa Rica”. Journal of Development Economics 57, 289-317.

Glewwe, P. (2002). "Schools and skills in developing countries: Education policies and socio-economic outcomes". Journal of Economic Literature 40, 436-482. 
Goldin, C. (1999). "Egalitarianism and the returns to education during the great transformation of American education". Journal of Political Economy 107, S65-S94.

Goldin, C., Margo, R.A. (1992). "The great compression: The wage structure in the United States at midcentury". Quarterly Journal of Economics 107, 1-34.

González, X., Miles, D. (2001). "Wage inequality in a developing country: Decrease in minimum wage or increase in education returns". In: Fitzenberger, B., Koenker, R., Machado, J.A.F. (Eds.), Economic Applications of Quantile Regression. Physica Verlag, Heidelberg.

Gosling, A., Machin, S., Meghir, C. (2000). "The changing distribution of male wages in the UK". Review of Economic Studies 67, 635-666.

Gottschalk, P. (1997). "Inequality, income growth, and mobility: The basic facts". Journal of Economic Perspectives 11, 21-40.

Gottschalk, P., Joyce, M. (1998). "Cross-national differences in the rise of earnings inequality: Market and institutional factors". Review of Economics and Statistics 80, 489-502.

Gottschalk, P., Smeeding, T.M. (1997). "Cross-national comparisons of earnings and income inequality". Journal of Economic Literature 35, 633-681.

Gregory, R.G., Vella, F. (1995). "Real wages, employment, and wage dispersion in US and Australian labor markets”. In: Freeman, R.B., Katz, L.F. (Eds.), Differences and Changes in Wage Structures. University of Chicago Press, Chicago.

Griliches, Z. (1977). "Estimating the returns to schooling: Some econometric problems". Econometrica 45, $1-22$.

Haider, S.J. (2001). "Earnings instability and earnings inequality of males in the United States: 1967-1991". Journal of Labor Economics 19, 799-836.

Hanson, H.G., Harrison, A. (1995). "Trade, technology and wage inequality". NBER Working Paper No. 5110.

Hanushek, E.A., Kimko, D.D. (2000). "Schooling, labor-force quality, and the growth of nations". American Economic Review 90, 1184-1208.

Harmon, C., Oosterbeek, H., Walker, I. (2003). "The returns to education: Microeconomics". Journal of Economic Surveys 17, 115-155.

Harmon, C., Walker, I. (1995). "Estimates of the economic returns to schooling for the UK". American Economic Review 85, 1279-1286.

Harmon, C., Walker, I., Westergaard-Nielsen, N. (2001). Education and Earnings in Europe. A Cross Country Analysis of the Returns to Education. Elgar, Cheltenham, UK.

Hartog, J., Oosterbeek, H., Teulings, C. (1993). "Age, wages and education in the Netherlands". In: Johnson, P., Zimmermann, K. (Eds.), Labour Markets in an Aging Europe. Cambridge University Press, Cambridge, UK.

Hartog, J., Pereira, P., Vieira, J. (2001). "Changing returns to education in Portugal during the 1980s and early 1990s: OLS and quantile regression estimators". Applied Economics 33, 1021-1037.

Heckman, J.J., Lochner, L., Taber, C. (1998). "Explaining rising wage inequality: Explorations with a dynamic general equilibrium model of labor earnings with heterogeneous agents". NBER Working Paper No. 6384.

Heckman, J.J., Polachek, S.W. (1994). "Empirical evidence on the functional form of the earnings-schooling relationship". Journal of the American Statistical Association 69, 350-354.

Hoegeland, T., Klette, T.J., Salvanes, K.G. (1999). "Declining returns to education in Norway? Comparing estimates across cohorts, sectors and over time". Scandinavian Journal of Economics 101, 555-576.

Juhn, C., Murphy, K.M., Pierce, B. (1993). "Wage inequality and the rise in returns to skill". Journal of Political Economy 101, 410-442.

Kahn, L.M. (1998). "Against the wind: Bargaining, recentralization and wage inequality in Norway 19871991". Economic Journal 108, 603-645.

Katz, K. (1999). "Where there no returns to education in the USSR? Estimates from Soviet-period household data". Labour Economics 6, 417-434.

Katz, L.F., Autor, D.H. (1999). "Changes in the wage structure and earnings inequality”. In: Ashenfelter, O., Card, D. (Eds.), Handbook of Labor Economics, vol. 3A. North-Holland, Amsterdam. 
Katz, L.F., Loveman, G.W., Blanchflower, D.G. (1995). "A comparison of changes in the structure of wages in four OECD countries”. In: Freeman, R.B., Katz, L.F. (Eds.), Differences and Changes in Wage Structures. University of Chicago Press, Chicago.

Keane, M.P., Prasad, E.S. (2002). "Changes in the structure of earnings during the Polish transition". IMF Working Paper WP/02/135.

Kim, D., Topel, R.H. (1995). "Labor markets and economic growth: Lessons from Korea's industrialization, 1970-1990”. In: Freeman, R.B., Katz, L.F. (Eds.), Differences and Changes in Wage Structures. University of Chicago Press, Chicago.

Krueger, A.B., Lindahl, M. (2001). "Education for growth: Why and for whom?”. Journal of Economic Literature 39, 1101-1136.

Krueger, A.B., Pischke, J. (1995). "A comparative analysis of East and West German labor markets: Before and after unification”. In: Freeman, R.B., Katz, L.F. (Eds.), Differences and Changes in Wage Structures. University of Chicago Press, Chicago.

Kyriacou, G. (1991). "Level and growth effects of human capital". C.V. Starr Center Working Paper No. 9126.

Levy, F., Murnane, R. (1992). "U.S. earnings levels and earnings inequality: A review of recent trends and proposed explanations”. Journal of Economic Literature 30, 1331-1381.

Light, A. (1998). "Estimating the returns to schooling: When does the career begin". Economics of Education Review 17, 31-45.

Lleras-Muney, A. (2002). "The relationship between education and adult mortality in the United States". NBER Working Paper No. 8986.

López-Acevedo, G. (2001). "Evolution of earnings and rates of return to education in Mexico". World Bank Policy Research Working Paper No. 2691.

Machado, J.A.F., Mata, J. (2001). "Earnings functions in Portugal 1982-1994: Evidence from quantile regression”. In: Fitzenberger, B., Koenker, R., Machado, J.A.F. (Eds.), Economic Applications of Quantile Regression. Physica Verlag, Heidelberg.

Mincer, J. (1974). Schooling, Experience and Earnings. Columbia University Press, New York.

Mitchell, M.F. (2001). "Specialization and the skill premium in the 20th century". Federal Reserve Bank of Minneapolis, Research Department Staff Report 290.

Montenegro, C.E. (2001). "Wage distribution in Chile: Does gender matter? A quantile regression approach". World Bank Policy Research Report on Gender and Development Working Paper Series No. 20.

Murphy, K.M., Riddell, W.C., Romer, P.M. (1998). "Wages, skills and technology in the United States and Canada". NBER Working Paper No. 6638.

Murphy, K.M., Welch, F. (1990). "Empirical age-earnings profiles”. Journal of Labor Economics 8, $202-229$.

Nehru, V., Swanson, E., Dubey, A. (1995). "A new database on human capital stocks in developing and industrial countries: Sources, methodology and results". Journal of Development Economics 46, 379401.

Nickell, S., Bell, B. (1996). "Changes in the distribution of wages and unemployment in OECD countries". American Economic Review Papers and Proceedings 86, 302-308.

OECD. (1996). Employment Outlook. OECD, Paris.

OECD. (2002). Education at a Glance. OECD Indicators 2002. OECD, Paris.

Peracchi, F. (2001). "Earnings inequality in international perspective". In: Welch, F. (Ed.), The Causes and Consequences of Increasing Inequality. University of Chicago Press, Chicago.

Peracchi, F. (2002). "The European Community Household Panel: A review”. Empirical Economics 27, 6390.

Polachek, S.W., Siebert, S.W. (1993). The Economics of Earnings. Cambridge University Press, Cambridge, UK.

Psacharopoulos, G. (1994). "Returns to investment in education: A global update". World Development 22, 1325-1343.

Psacharopoulos, G., Patrinos, H.A. (2002). "Returns to investment in education: A further update". World Bank Policy Research Working Paper 2881. 
Revenga, A. (1995). "Employment and wage effects of trade liberalization: The case of Mexican manufacturing”. World Bank Policy Research Working Paper No. 1524.

Rutkowski, J.J. (2001). "Earnings inequality in transition economies of Central Europe: Trends and patterns during the 1990s". World Bank Social Protection Discussion Paper No. 0117.

Schultz, T.W. (1961). "Investment in human capital". American Economic Review 51, 1-17.

Schultz, T.W. (1963). The Economic Value of Education. Columbia University Press, New York.

Schmitt, J. (1995). "The changing structure of male earnings in Britain, 1974-1988”. In: Freeman, R.B., Katz, L.F. (Eds.), Differences and Changes in Wage Structures. University of Chicago Press, Chicago.

Siow, A. (1984). "Occupational choice under uncertainty". Econometrica 52, 631-645.

Smeeding, T., O’Higgins, M., Rainwater, L. (1990). Poverty, Inequality and Income Distribution in Comparative Perspective. Luxembourg Income Study (LIS). Urban Institute Press, London.

Svejnar, J. (1988). "Labor markets in the transitional central and east European countries". In: Ashenfelter, O., Card, D. (Eds.), Handbook of Labor Economics, vol. 3B. North-Holland, Amsterdam.

Skyt Nielsen, H.S., Rosholm, M. (2001). "The public-private sectore wage gap in Zambia in the 1990s: A quantile regression approach”. In: Fitzenberger, B., Koenker, R., Machado, J.A.F. (Eds.), Economic Applications of Quantile Regression. Physica Verlag, Heidelberg.

Spence, A.M. (1974). “Job market signaling”. Quarterly Journal of Economics 87, 355-374.

Teal, F. (2000). "Real wages and the demand for skilled and unskilled male labour in Ghana's manufacturing sector: 1991-1995". Journal of Development Economics 61, 447-461.

ter Weel, B. (2003). "The structure of wages in the Netherlands, 1986-1998”. Labour 17, 361-382.

Trostel, P., Walker, I., Wooley, P. (2002). "Estimates of the economic return to schooling for 28 countries". Labour Economics 9, 1-16.

UNESCO. (1997). International Standard Classification of Education. ISCED 1997.

Vieira, J.A.C. (1999). "Returns to education in Portugal". Labour Economics 6, 535-541.

Vila, L., Mora, J. (1998). "Changing returns to education in Spain during the 1980s". Economics of Education Review 12, 173-178.

Weisberg, J. (1995). "Returns to education in Israel: 1974 and 1983”. Journal of Education Review 14, 145154.

Weiss, A. (1995). "Human capital vs. signalling explanations of wages". Journal of Economic Perspectives 9 , $133-154$.

Welch, F. (1970). "Education in production”. Journal of Political Economy 78, 312-327.

Welch, F. (1999). "In defence of inequality". American Economic Review Papers and Proceedings 89, 2-17.

Willis, R.J. (1986). "Wage determinants: A survey and reinterpretation of human capital earnings functions". In: Ashenfelter, O., Layard, R. (Eds.), Handbook of Labor Economics. North-Holland, Amsterdam.

Zarkin, G.A. (1985). "Occupational choice: An application to the market for public school teachers". Quarterly Journal of Economics 100, 409-446. 